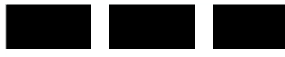 \\ $\square$ \\ THE WILLIAM DAVIDSON INSTITUTE \\ AT THE UNIVERSITY OF MICHIGAN
}

\section{The Economic Value of Regulated Disclosure: Evidence from the Banking Sector}

\author{
By: Solomon Tadesse
}

William Davidson Institute Working Paper Number 875

January 2006 


\title{
The Economic Value of Regulated Disclosure: Evidence from the Banking Sector
}

\author{
Solomon Tadesse ${ }^{*}$ \\ Stephen M. Ross School of Business \\ University of Michigan
}

This version: January 2006

\begin{abstract}
The study examines the economic consequences of regulated disclosure in the banking sector, focusing on its impacts on the stability of banking systems. In a cross-country study of banking systems across 49 countries in the $90 \mathrm{~s}$, I find that banking crises are less likely in countries with greater regulated disclosure and transparency. Specifically, banking systems are less vulnerable to crisis if supported by financial reporting regimes characterized by (i) more comprehensive disclosure (ii) more timely financial reporting (iii) more informative reporting, and (iv) more credible financial disclosure. To the extent that banking crises are costly, the paper documents the positive impact of accounting information to the real sector of the economy.

JEL classification: M41, M42, L51, G18, G21, K23,

Key Words: $\quad$ Regulated disclosure, informativeness, timeliness, credibility, banking crisis
\end{abstract}

\footnotetext{
* Corresponding author: Stephen M. Ross School of Business, University of Michigan, Ann Arbor, MI 48109-1234. E-mail: stadesse@umich.edu.
} 


\section{Introduction}

Regulation of disclosure is pervasive around the world. Surprisingly, there is little empirical research on the economic value of mandated disclosure, particularly in a cross-country setting. Healy and Palepu (2001, p. 415) notes that empirical research on disclosure regulation, in general, is 'virtually nonexistent'. Furthermore, the benefit of disclosure regulation, and hence greater transparency, is not theoretically unambiguous (e.g., Coffee, 1984).

I document evidence on the economic consequences of greater disclosure and transparency in an international setting by examining the impact of bank-disclosure requirements on banking system stability in a large cross-section of countries. Although banking crisis has been a common feature of banking systems (see, e.g., Miron (1986)), recent crises have been more frequent and severe. There is significant variation in the distribution of crises across countries; some countries being frequent targets (see Hoggarth and Saporta, 2001). Bank regulations, including those on disclosure and auditing, also vary considerably across countries (Barth et al., 2004). Moreover, banks are highly regulated business entities, with bank financial reports much a product of the regulatory framework in which they operate. Thus, investigating banking system performance (or stability) in the context of enormous variations in national reporting regimes provides a fertile ground to study the economic value of regulated disclosure.

Reflecting the broader debate on the economic consequences of regulated disclosure, the role of bank transparency ${ }^{1}$ to banking-system stability is controversial. Theory provides conflicting predictions about the benefits of greater transparency. The 'Transparency-Stability' view holds that greater disclosure and the consequent transparency facilitates the efficient allocation of resources by improving market discipline via reducing informational asymmetry. Increased transparency permits greater market discipline whereby strong banks are rewarded for their risk management and performance and weak banks are penalized with higher costs of raising capital and deposits, thereby enabling early detection of

\footnotetext{
${ }^{1}$ I define bank transparency, following Bushman, Piotroski and Smith (2004), as "the widespread availability of bank-specific information concerning ... banks in the economy to those outside the bank ((Bushman et al. (2004, p $4)$ ), and words in italic are mine). Bank transparency reflects regulated bank-level disclosure, private acquisition of bank-level information, and dissemination of bank information in the economy. I focus on the impact of regulated bank disclosure, but I also examine the role of the overall increase in transparency for completeness.
} 
weak banks before they drag the entire banking system into crisis. On the other hand, the 'Transparencyfragility' view holds that greater disclosure may engender banking-system instability because it may lead to projection of information about problems of specific banks as indicator of widespread problems in the banking system, thereby leading to bank-runs or stock market collapse (Calomiris and Mason, 1997; Gilbert and Vaughan, 1998; and Kaufman, 1994). That is, disclosure creates negative externalities. Disclosure of financial problems at a bank level may lead to the bank's failure through a bank run. It may also lead to an overreaction in the financial markets, jeopardizing the ability of the bank to raise capital. This lack of investor confidence could spread to the entire banking system, causing systemic banking failure. In that case, rather than providing market discipline to improve resource allocation, more disclosure and transparency leads to the collapse of the banking system, causing in failure of both strong and weak banks alike.

The paper studies the impact of disclosure regulations meant to increase bank transparency on the likelihood of suffering a systemic banking crisis ${ }^{2}$ based on data on banking crisis incidence and disclosure regulations across 49 countries over the period of 1990 and 1997. Using the conceptual framework advanced in Bushman, Piotroski and Smith (2004), it examines the impacts on banking crisis probability of disclosure regulations meant to increase bank disclosure quality, including the intensity, informativeness, timeliness, and credibility of bank disclosures. It also explores the impact of overall bank transparency, which reflects the disclosure regulations meant to increase the quality of bank reports as well as the degree of private acquisition of information, and dissemination of bank information.

To draw accurate inferences about the impact of bank-transparency on bank crisis, I control for a number of factors that may influence banking fragility. These include macro economic sources of bank

\footnotetext{
${ }^{2}$ I use banking crisis to mean systemic banking crisis. Instability in the banking system may refer to both individual bank failures and banking system crises. The former refers to a failure of a financial institution, and the latter describes the situation where a failure of an individual financial institution leads to many simultaneous failures of other financial institutions. This is different from 'contagion' where an individual failure leads to 'one or more sequential failures'. Banking crisis could be 'systemic' or borderline. 'Systemic' banking crises are episodes of crises where most or all bank capital in the system is exhausted. I provide the detailed criteria by which I classify banking crisis in section 3 below.
} 
instability, such as the level of inflation and external terms of trade, and cross-country differences in the banking industry structure such as the degree of bank competition, bank concentration, and regulations on bank entry, activity and ownership. I also control for differences in the overall institutional quality, as well as differences in the macro economic environment of banks as reflected in the level of economic development.

I find that disclosure regulation fosters banking system stability. Specifically, banking systems are more likely to be stable in countries with regulations that require more comprehensive, more informative, more timely and more credible disclosure. I report that greater bank transparency, in general, lowers the likelihood of systemic banking crisis, controlling for the effects of macroeconomic sources of instability and banking market structure. The positive impact of greater disclosure on the real sector of the economy via enhancing banking-system stability is also economically large. Based on historical data on the costs of banking crisis, the impact of enhanced disclosure and transparency could amount to a saving as high as 1.7 percent of GDP per crisis episode.

The paper is related to three distinct areas of accounting and economic research. First, it contributes to the limited empirical research ${ }^{3}$ on the economics of regulated disclosure (see Healy and Palepu (2001) for a recent survey). The few studies in this area (Stigler, 1964; Benston, 1969; and, Benston, 1973) investigate the economic impacts of the Security Acts of 1933 and 1934 in the U.S., finding no significant value to investors. Others challenge these findings (see Coffee, 1984), including Bushee and Leuz (2003) who find some evidence of economic benefits to SEC disclosure regulation. This paper provides evidence to the debate by documenting the economic value of regulation of disclosure in preventing banking crisis.

\footnotetext{
${ }^{3}$ The mandated disclosure literature traditionally attempts to compare disclosure under regulated environments against disclosure in unregulated environments. I make the comparisons across environments that are more or less regulated. The cross-country setting of the research design allows me to make such comparisons. Note also that there is a large literature on the economic impacts of mandated changes in accounting standards (Watts and Zimmerman, 1986; Fields, et al., 2001), which, along with capital-markets research (see Kothari, 2001), and voluntary disclosure research (see, Cole, 2001), focuses on the relation between reported accounting numbers and stock returns. While the focus of these groups of studies is on either (a) the capital market effects of changes in accounting methods, or (b) the effects of changes in corporate disclosure within the context of the same disclosure-regulatory regime (usually the U.S.), this paper examines the impact of variations in disclosure regulations themselves across a wide range of countries.
} 
Second, the paper is related to the growing literature on the role of financial information in corporate governance. In a recent paper on accounting information and governance, Bushman and Smith (2001) provide a roadmap of future research agenda that includes investigation of the role of accounting information in influencing real economic performance. They suggest cross-country design as the most powerful setting for this type of research. Bushman, Piotroski, and Smith (2004) provide a framework for conceptualizing and measuring corporate transparency. This paper investigates the consequence in terms of bank performance and crisis probability of banking system transparency (in the context of Bushman et al. (2004)), but with a focus on the component of transparency that is attributable to regulated disclosure. By so doing, it documents the economic value of accounting information.

As a cross-country study, the paper is related to prior international studies on financial reporting such as on disclosure regulation, enforcement and disclosure intensity (e.g., Jaggi and Low, 2000; Hope, 2003); the value-relevance of earnings (e.g., Alford et al., 1993; Francis et al., 2003; Geunther and Young, 2000; Land and Lang, 2003); earnings management (e.g., Bhattacharya et al., 2003; Leuz et al., 2003); earnings timeliness (e.g., Ball et al., 2000); audit quality (e.g., Francis et al., 2003); and analyst activity (e.g., Bushman et al., 2005). While this literature explores, to the most part, the determinants of some dimension of firms' information environment (or corporate transparency), this paper goes beyond by investigating the impact of transparency on economic performance (i.e., banking fragility).

Third, in the banking literature, the paper contributes to the growing empirical literature on banking crises. Demirguc-Kunt and Detragiache (2005) and Beck et al. (2005) investigate macroeconomic factors and banking market structure as determinants of banking crisis. Cull, Senbet and Sorge (2005) and Demriguc-Kunt and Detragiache (2004) examine the relations between deposit insurance design features and banking crises. Barth, Caprio and Levine (2004) examine the relation between bank regulation and banking crisis. Yet this literature does not address the role of disclosure and transparency on banking crisis. Baumann and Nier (2004) recently examine the relation between banklevel disclosure, and firm performance in terms of stock price volatility. In contrast, this paper investigates the role of disclosure regulation in preventing systemic banking crises. 
The rest of the paper is organized as follows. Section 2 provides the theoretical discussions on the relation between regulated disclosure and crisis, developing testable hypotheses. Section 3 provides a detailed description of the data and methodology. Section 4 presents the results, and Section 5 concludes the paper.

\section{Disclosure Regulations and Banking System Stability: Theory}

In the general regulation theory, public regulation is justified by market failure that can result from (i) the presence of market power, (ii) the importance of externalities, or (iii) asymmetric information. Applying this general theory, disclosure regulation is usually associated with informational asymmetry or some form of externality (see, e.g., Healy and Palepu, 2001).

Informational asymmetry leads to adverse selection between savers and entrepreneurs, causing misallocation of capital. Entrepreneurs have better information about, and incentive to inflate the value of their investment opportunities. In the context of banking, a large literature attributes the problems of bank runs and bank panics to informational asymmetry (see Bryant, 1980; Diamond and Dybvig, 1983; Minkew, 1986; and Bernanke and Gertler, 1990). Informational asymmetry between a bank and its depositors could precipitate a bank run, hastening the bank's failure. This is when a bank is subject to excessive withdrawals by uninformed depositors due to fear of real or imagined impending bank failure. A bank run may then spread to other banks, again because of informational asymmetry, endangering the stability of the banking system.

One well-known solution to the problem of asymmetry is regulated disclosure. Others include optimal contracting and the use of information intermediaries (see Healy and Palepu, 2001). Leftwich, (1980) and Watts and Zimmerman (1986) suggest that, by creating minimum disclosure requirements, regulation of disclosure reduces the informational gap between the 'informed' and 'uninformed' agents in the economy.

Externalities provide a second justification for regulated disclosure. Leftwich (1980) and Watts and Zimmerman (1986) argue that accounting information can be viewed as a public good, subject to the 
free-rider problem. Existing shareholders pay for its production but cannot charge prospective investors for its use. The resulting imbalance between private and public value of information leads to its underproduction, necessitating mandatory disclosure.

Other externalities have also been discussed in the literature. For example, information generated by one firm could confer benefits to others who did not pay for its production in the form of liquidity spillovers (Dye, 1990; Admati and Pfleiderer, 2000). Disclosure can also generate negative informational externalities. Fishman and Hagerty (1989) note that, due to information costs, investors may be able to analyze only few firms. They show that greater disclosure, in that case, may lead to lower price efficiency by attracting investors away from other firms.

Negative externalities are a particularly acute concern in the banking sector. The failure of a bank could spread to other banks (or firms) that are linked to the failing bank, in addition to the externalities it creates to its depositors. Bank runs and generalized bank panic (or crisis), due to these externalities, were commonplace and their history is as long as that of the modern banking system (see, e.g., Miron (1986)) ${ }^{4}$. In fact, bank regulation (not just only in areas of disclosure) has evolved to contain these externalities.

Informationally, greater disclosure may generate negative externalities in banking. Disclosure may lead to interpretation of specific information about banks' financial conditions as indication of widespread problems in the banking system, leading to bank runs or stock market collapse (Calomiris and Mason, 1997; Gilbert and Vaughan, 1998; and Kaufman, 1994). Disclosure of financial problems at a bank may lead to the bank's failure through a bank run and may cause an overreaction in the financial markets. The lack of investor confidence could spread to the entire banking system causing banking panic, suggesting that greater disclosure may foster banking system instability.

Thus the impacts of regulated disclosure on banking system stability are intricately complex. On the one hand, the informational asymmetry and the positive externality explanations of regulated

\footnotetext{
${ }^{4}$ The U.S. experienced eleven banking panics between 1800 and 1900 (Baim and Calomaris, 2001). Miron (1986) provides an impressive account of bank panics in the U.S. For example, the probability of a bank panic in a given year during the period 1890 through 1908 is estimated to be one in three. The average annual real growth rate in those periods would have been 3 percent higher in the absence of banking panic.
} 
disclosure predict that disclosure and the consequent transparency enhances banking system stability by enabling market participants to better assess bank risk and performance. This is the "TransparencyStability' view. On the other hand, regulated disclosure could exasperate banking system instability by creating negative informational externalities. This is what I call the "Transparency-Fragility" view. If the "Transparency-Stability" view holds, we should find that increased regulated disclosure reduces the likelihood of banking system crises, controlling for other sources of banking system instability. If the alternative view is true, we should observe a positive relation between banking crisis probability and regulated disclosure on average. The disclosure-stability relation is, therefore, a matter of empirical question, which I investigate in the sections to follow.

\section{Data and Methodology}

\section{A. Methodology}

I examine the relation between bank transparency and banking system stability using a

multivariate logit model. I estimate the probability that a systemic banking crisis will occur in a particular country in a particular time, assuming this probability is a function of a set of explanatory variables of interest, $\mathrm{X}$, and control variables, $\mathrm{Z}$. Let $\mathrm{Crisis}_{\mathrm{it}}$ be an indicator variable that takes 1 when country $\mathrm{i}$ is in a systemic banking crisis in year $\mathrm{t}$, and 0 otherwise. Let $\mathrm{P}_{\mathrm{it}}$ be the probability (conditional) that systemic crisis occurs in country $i$ in period t. The natural log of this likelihood of crisis given the explanatory variables, where $\beta$ and $\lambda$ are vectors of parameters to be estimated and $F\left(X_{i t} \beta ; Z_{i t} \lambda\right)$ is the cumulative logistic function evaluated at $\left(X_{\mathrm{it}} \beta ; Z_{\mathrm{it}} \lambda\right)$, is given by,

$$
\operatorname{LnL}=\sum_{i=1}^{N} \sum_{t=1}^{T}\left(\text { crisis }_{i t} \operatorname{Ln}\left(F\left(X_{i t} \beta ; Z_{i t} \lambda\right)\right)+\left(1-\text { crisis }_{i t}\right) \operatorname{Ln}\left(1-F\left(X_{i t} \beta ; Z_{i t} \lambda\right)\right)\right.
$$

where, $\mathrm{X}$ is a vector of variables of interest and includes variables representing bank transparency including regulated disclosure, and $\mathrm{Z}$ is a set of control variables that include variables representing the banking industry structure, the quality of overall institutions and the macro economic environment of countries. 
In modeling the likelihood of crisis, I use the logistic function as the underlying probability distribution $^{5}$. This conforms to earlier studies of banking crises (see, e.g., Demirguc-Kunt et al., 2005; Demirguc-Kunt et al., 2004). In this logit specification, the estimates of the coefficients $\beta$ and $\lambda$ do not represent a marginal effect on the likelihood of crisis for a unit change in the underlying independent variable. Rather, the coefficients measure an increase in the natural $\log$ of the odds ratio, $\ln \left[\mathrm{P}_{\mathrm{it}} /\left(1-\mathrm{P}_{\mathrm{it}}\right)\right]$, and this quantity depends on the values of the independent variables at which the likelihood is evaluated. A change in the independent variables will have different (i.e., nonlinear) effects on the likelihood of crisis depending on the initial crisis probability.

In the main regressions, I define each year for a country as either a crisis year or a non-crisis year, and examine the relation between crisis probability in an average year and country transparency. Each country is included eight times (1990 through 1997) in a pooled time-series cross section. Such a specification may introduce a problem of correlated errors (or lack of independence) because crisis episodes may be correlated across years for a country and/or across countries. I address these methodological issues in the robustness section below in a number of ways, including redefining the crisis event as a single event for a country, specifying the model as a panel with random effects, and estimating it as a cross-country regression.

\section{B. Variables}

Crisis, the dependent variable, is an indicator variable that takes 1 if a country has undergone systemic banking crisis in a particular year during the period 1990 through 1997. I construct the variable primarily based on the database of World Bank dataset on Financial crisis (see World Bank (2003)), which provides comprehensive information on episodes of banking crisis since the 1970s for a large sample of countries. I supplement this information with data in Demirguc-Kunt and Detragiache (2005), particularly in dating the episodes. Systemic crises are, in general, episodes in which most or all bank

\footnotetext{
${ }^{5}$ I also use a probit model for robustness. No discernable differences were shown between the two sets of estimates. On theoretical ground, there is no basis to prefer logit to probit and vise versa; they both are widely used in empirical economic research.
} 
capital in the banking system is exhausted. Consistent with previous research (Barth et al., 2004;

Demirguc-Kunt, 2005), episodes are considered systemic if non-performing assets account for more than $10 \%$ of total assets, or rescue costs amount to more than $2 \%$ of GDP, or the crisis involved large-scale nationalizations, or the crisis involved bank runs where emergency measures were taken. I identify 21 such episodes in the 1990s. I focus on the 1990s because I have data on disclosure and transparency - my independent variables - only for this period.

I use, as vector X, various measures of bank-transparency, including regulated-disclosure, with a set of control variables (the vector Z), to explain incidence of systemic banking crises (Crisis). The focal explanatory variables - the measures of bank-transparency - are constructed using cross-country data on bank regulatory provisions that regulate local disclosure practices by banks. The data is obtained from a recent database on bank supervision and regulation maintained by the World Bank (Barth et al., 2001). The database is constructed based on surveys of national bank regulatory and supervisory authorities in 1998 and 1999. The data from the survey have been extensively used in recent bank regulation studies (e.g., Barth et al., 2004; Beck et al., 2003; Cull et al., 2005; Cleassens and Laeven, 2004; and DemirgucKunt, and Detragiache, 2004). I utilize the survey responses on questions related to disclosure and auditing to construct the relevant indices of bank-transparency.

I use the framework of Bushman, Smith and Piotroski (2004) to identify and organize the properties of regulated disclosure relevant to enhancing transparency. Regulated disclosure enriches the informational environment of the reporting firm. Bushman et al. (2004)] provide a framework for conceptualizing the informational environment of the firm. They identify three components of corporate transparency: the quality of corporate reporting, the degree of private information acquisition (e.g., by analysts), and the availability of information-dissemination infrastructure (e.g., well- developed media). The quality of corporate reporting is the foundation of transparency, and is, to the most part, a function of regulated disclosure. Bushman et al. (2004) further identify four properties of corporate reporting quality: disclosure intensity (or comprehensiveness), disclosure informativeness, disclosure timeliness and disclosure credibility. Figure 1 summarizes the Bushman et al. (2004) framework. 
To operationalize these conceptual constructs, Bushman et al. (2004) use measures of realized disclosure practices, namely disclosure rankings from the Center for International Financial Accounting Research (CIFAR). Instead, because my focus is on regulated disclosure, I operationalize the variables in terms of the corresponding regulatory provisions related to each conceptual construct. The measurement of the key constructs (i.e., the independent variables), using regulatory disclosure provisions, is as follows.

Disclosure Intensity measures the extent and comprehensiveness of financial reporting required of banks. Based on the survey responses, it specifically measures whether bank financial reports include information on bank risk management practices, accurately presents non-performing loans, provides a full picture of bank activity by reporting consolidated financial statements, and presents comprehensive information by reporting off-balance sheet transactions. The variable is constructed as a principal component of the following indicator variables: (i) a variable that takes the value 1 if banks are required to disclose risk management procedures to the public; (ii) a variable that takes 1 if the disclosure regulation requires that accrued income on non-performing loans (NPL) should not be reported in the bank's income statement; (iii) a variable that assumes 1 if consolidated financial statements of bank and non-bank financial subsidiaries are required; and (iv) a variable that takes 1 if off balance sheet items need to be disclosed to the public. These variables are a 0 or 1 indicator variables, and a value 1 represents good disclosure practice with respect to the disclosure item the variable denotes. The source of this data is the World Bank survey of bank regulation and supervision described in Barth et al. (2001).

Non-reporting of income on NPL provides a more accurate representation of the financial health of the bank; consolidated financial statements are considered to be comprehensive; reporting off-balance sheet transactions provides a more complete picture of the conditions of the bank; and reporting risk management procedures enable investors to assess the risk profile and valuation of the bank better. Hence, these variables quantify good disclosure practices in terms of enhancing disclosure comprehensiveness. To the extent that increased disclosure results in greater transparency and the consequent market discipline, the variable Disclosure Intensity will be associated with lower rate of bank 
fragility. If, on the other hand, increased disclosure causes misinterpretation and panic, the variable could be associated with greater fragility.

Disclosure Informativeness measures the degree to which bank disclosure accurately represents the financial conditions of banks. For example, reporting interest income from non-performing loans as part of bank income overstates the true economic performance of the bank, as does the selective reporting of bank activities. Disclosure Informativeness is measured by aggregating whether non-performing loans are accurately presented and whether banks are required to present their bank and non-bank activities in a consolidated financial statement.

Disclosure Timeliness measures the degree to which bank disclosure is close to the decision time-point of potential users of the information. This is a function of the frequency with which information is available to users. Using survey data of accounting reporting practices around the world by CIFAR, Bushman et al. (2004) construct an index of the average frequency and comprehensiveness of interim reports for a sample of 60 countries. The frequency of interim reports as reported by CIFAR is a matter of country's disclosure regulation (see CIFAR, 1995). I use this index as a proxy for disclosure timeliness.

Disclosure Credibility measures the degree to which bank-generated disclosure is subject to verification by an external audit that is independent, professional and rigorous as reflected by the regulations that govern bank-auditing practices. Specifically, it measures the stringency of external audit in terms of whether external audit is compulsory, whether the scope of external audit is mandated, whether there is a license requirement for auditors, and whether auditors have independence in reporting to supervisory bodies. The variable is a principal component of the following five indicator variables: (i) a variable that takes 1 if external audit of banks is compulsory in the country. (Such audit is compulsory in all countries with the exception of China, Italy and Taiwan); (ii) a variable that takes a value of 1 if there are specific regulatory requirements for the extent of audit; (To the extent that audits are costly, in the absence of minimum requirements, audit services could be undersupplied. Hence, the presence of such regulation improves audit services.); (iii) a variable that takes 1 if auditors are required to be 
licensed or certified; (iv) an variable that takes 1 if auditors' report should be given to supervisory agency; and, (v) a variable that takes 1 if supervisors can meet external auditors to discuss audit report without bank approval.

Quality third-party audits provide validation that bank-produced financial statements represent the financial condition of the bank as is, thereby increasing the credibility of the bank disclosure. To the extent that this enhances the ability of market participants to accurately assess the risk profile of the bank, and strengthen market discipline, increases in these variables would be associated with lower rates of crisis.

Regulated-Disclosure Quality is a measure of the effectiveness of the disclosure regulations in enhancing the quality of bank reports. It reflects the effectiveness of disclosure regulations in enhancing the comprehensiveness, informativeness, timeliness and credibility of financial reports, and, as a construct, it corresponds to Bushman et al. (2004)'s concept of corporate reporting quality. The variable is constructed as a principal component of the variables disclosure intensity, disclosure informativeness, disclosure timeliness and disclosure credibility.

Tables 1 through 3 provide a summary of these variables. Regulated-Disclosure Quality exhibits a wide variation across countries ranging in value between -2.99 (Kenya) and 1.259 (Canada). Countries high on regulated-disclosure quality tend to have lower incidence of crisis. Countries that have experienced crisis in the 90 s score lower on regulated-disclosure quality and disclosure intensity, timeliness and credibility (see Table 2). Regulated-Disclosure Quality is negatively correlated with incidence of banking crisis (though the relation is not statistically significant) in Table 3. The same is true of the relations between incidence of crisis and the variables disclosure intensity, disclosure informativeness, disclosure timeliness and disclosure credibility. These variables also exhibit wide variations across countries. For example, disclosure intensity ranges in value from -1.917 (Ghana and Guatemala) to 1.342 (e.g., the U.K and Switzerland). Disclosure credibility varies from -6.725 (Italy) to 0.554 (e.g., the U.S. and Switzerland). Italy scores the lowest because, out of the five measures that constitute external audit stringency, Italy's bank regulation requires only one which is the requirement 
that auditors should be licensed. The other country with low score, Japan, provides two requirements bank audit is compulsory and that auditors should be licensed.

Private Information Acquisition measures the degree of private information processing and gathering activity by investors (or on behalf of investors) other than the reporting bank. I use the average number of analyst-following per bank in a country as a proxy for the amount of private information acquisition. It is the sum of analysts (following) each bank in the country divided by the number of banks. Note that we are interested in measuring the information environment of banks (not firms). Hence, the measure of private information acquisition using analyst following, is calculated as analyst followings of banks.

Information dissemination, following Bushman et al. (2004), measures firm-specific information dissemination by the degree of penetration of the media channels in the economy. The variable is the average rank of countries' per capita number of newspapers and televisions as reported by World Development indicators obtained from Bushman et al. (2004).

Bank Transparency represents the availability of bank-specific information to economic agents outside the bank, and reflects (i) the quality of reporting that includes the intensity, informativeness, timeliness and credibility of disclosure, (ii) the degree of private acquisition of information, and (iii) the degree of information dissemination. It is measured as a principal component of the variables Regulated-

\section{Disclosure Quality, Private Information Acquisition and Information Dissemination.}

Tables 1 through 3 provide a summary of these variables. The variables exhibit enormous variability across countries. For example, bank transparency ranges from -2.522 (Kenya) to 1.48 (U.S.)

(Table 2). Information dissemination ranges in value between 23.05 and 96.72 , reflecting the unequal development of communication infrastructure in our sample of countries. Countries high on bank transparency, regulated-disclosure quality and information dissemination tend to also have lower incidence of banking crisis (see Table 2). In Table 3, bank transparency and crisis exhibit significant negative correlation, as does information dissemination and crisis. Also, the quality of regulated 
disclosure reinforces the degree of information acquisition, and the quality of information dissemination in increasing the overall information environment in the country. They tend to be complements rather than substitutes.

Control Variables: To examine the relations between bank transparency and banking crises, I control for a number of factors. To control for macroeconomic (in) stability that are likely to affect the quality of bank assets thereby crisis probability, I use the average rate of inflation and the external terms of trade. This is consistent with previous research (e.g., Barth et al., 2004; Cull et al., 2005). Inflation serves as a proxy for macroeconomic mismanagement that adversely affects the economy and the banking system. A chronically inflationary environment deteriorates the quality of bank assets and I expect inflation to increase banking crisis probability. External terms-of-trade captures the macro economic shocks that could adversely affect banks by increasing their non-performing loans. Improvements in terms-of-trade are expected to be associated with decreases in the likelihood of banking crises. Per capita GDP is included to control for the level of development of the country, and serves as a proxy for the quality of the overall institutional environment. Banking sector problems could result from weaknesses in the legal system that permeates widespread fraud, and/or weaknesses in the administrative capacity that is reflected in loose prudential supervision and regulation of the banking system. Per capita GDP is expected to measure differences across countries on these dimensions.

Recent research identifies banking industry structure as a potential determinant of banking crises. Beck et al. (2005) report that banking crisis is lower in countries with concentrated banking system and both Beck et al. (2003) and Barth et al. (2004) find that countries with banking industry structure that allows more competition and less regulatory restrictions have lower incidence of bank crises. I use bank concentration, the share of assets of the three largest banks, to control for banking system concentration. I expect concentrated banking to be associated with less likelihood of crisis - a negative coefficient. To control for the degree of competition in the banking sector, I use a variable, bank competition, which is a measure of banking competitiveness conduct obtained from Claessens and Laeven (2004). Using a methodology from Panzar and Rosse (1987), Claessens and Laeven (2004) develop an index of 
competitiveness based on bank-level data in a large cross-section of banking systems, as a sum of the elasticity of bank revenue to changes in input prices. The variable, bank competition, takes values between 1 (perfect competition) and 0 (monopoly), with less than 1 representing monopolistic competition. Claessens and Laeven (2004) find that banking systems with less entry restrictions, less restriction to foreign bank entry and less restriction as to what activities banks can get into are more competitive, but find no inverse relation between competitiveness and concentration. Barth et al. (2004) and Beck et al. (2005) report an inverse relation between restrictive regulations against entry and activity, and banking crisis. I expect greater bank competition in the banking system to be associated with a lower likelihood of banking crisis. I also use banking entry restrictions (the number of new bank applicants for bank license denied), and regulatory restrictions on banking activity from Barth et al. (2004) as alternative measures of bank competition, and find similar results.

Table 1 summarizes the variables. The data displays significant variations in the macroeconomic conditions and banking industry structure. Average log of inflation ranges from 0.01 to 0.46 and, consistent with priors, is positively correlated with incidence of crisis (Table 2). Bank concentration ranges from a low of 19 percent to a high of 100 percent, while the measure of bank competition ranges between 0.41 and 0.92 , indicating monopolistic competition as the dominant market structure of banking systems around the world. Consistent with prior research, bank competition tends to be associated with lower incidence of crisis (Table 2). Developed countries, in general, appear to be less vulnerable to crisis. Per capita GDP has a negative correlation with banking crisis. Developed countries also tend to have better informational environments, reflecting the better quality of informational, supervisory and regulatory institutions. This is shown in the high level of correlations between per capita GDP and the informational variables.

\section{Sample Selection}

I attempt to explain the likelihood of suffering from banking crisis given information on the regulatory environment governing bank disclosure in different countries. The data on regulation of disclosure, from the World Bank, is based on surveys of bank supervisory bodies in the late $90 \mathrm{~s}$. Though 
Barth et al. (2004) reports that the regulatory and supervisory environment does not change significantly over time, it is reasonable to assume that the survey results reflect the period closest to when the survey was taken more accurately than the distant past. Hence, due to these data limitations, and to minimize the problem of reverse causality, I focus on explaining incidence of banking crisis in the 90s (1990 through 1997). For this period, I cover all countries with data on bank regulation and supervision and data on crises as my sample. This results in a sample size of 49 countries with 21 episodes of crises (not counting the length of time of each crisis) involving 20 countries. The total number of crisis years is 67 out of the total number of 392 panel observations. Appendix I presents the list of countries in the sample and the episodes of crisis in the 1990s.

As noted, we have data limitation where the transparency variables are drawn from the period after when we observe the countries' crises experiences. The survey data on which the transparency measures are based is simply not available before 1997. This may raise a concern that the transparency data would reflect the banks' responses to crises episodes, hence introducing reverse causality. We would expect a country to improve its disclosure practices in response to major episode of crises. One can effectively address, and I do in the robustness section below, the reverse causality issue through instrumental variables approach, where I examine the relation between the exogenous component of transparency - i.e., that part of transparency explainable by exogenous instruments (such as differences in legal origin of countries) - and crisis probability, the dependent variable. In addition, if it is true that a country improves its disclosure after a crisis episode, one would expect, on average, an occurrence of banking crisis to be followed by improvements in disclosure and transparency - i.e., a positive relation between crisis probability and transparency. The effect of this data problem would, therefore, be to bias the results in favor of the 'Transparency-Fragility' hypothesis, and against the 'Transparency-Stability' thesis. Hence, in the case of a finding of positive relation between crisis probability and disclosure, caution should be exercised in interpreting the results. However, once causality is accounted for, a finding of negative relation would be a strong evidence for the 'Transparency-Stability' view, given the presumed 'bias' in the data. 
With these qualifications, I use the cross-country variation in the transparency variables as observed in 1997 as a proxy for variations in the disclosure climate during the sample period. That is, it is assumed that, while there is cross-country variation, the relative rankings of the countries in their level of transparency remains stable over this short period of time. Barth et al. (2004), for example, reports that the regulatory and supervisory environment of which bank disclosure is a consequence does not change significantly over time. Table 3, also provides evidence consistent with this assumption. Despite the fact that the crises countries presumably may have improved their transparency, as a group, these countries score significantly lower than the non-crises countries in all measures of transparency.

\section{Results}

I begin the discussion in this section by examining the relation between overall bank transparency (which reflects the effects of regulated disclosure) and banking system-stability. I will then focus on the role of regulated-disclosure - the focal variable of interest - in subsection B below, with a detailed exploration of the role of its components: disclosure intensity, disclosure informativeness, disclosure timeliness and disclosure credibility.

\section{A. Bank Transparency and Banking Crises}

Table 4 indicates that greater overall Bank Transparency, which reflects regulated disclosure as well as the degree of private information acquisition and dissemination, reduces the likelihood of suffering a systemic banking crisis. Bank Transparency enters the empirical models with a large statistically significant negative sign. The inverse relation between bank transparency and banking fragility holds controlling for macroeconomic sources of instability as well as banking industry structure. In column (2), transparency is associated with a lower likelihood of systemic banking crisis, controlling for macroeconomic sources of bank instability such as inflation and external terms-of trade. Columns (3) and (4) indicate that transparency lowers the likelihood of banking crisis controlling for banking industry structure, where the latter is measured by the degree of bank concentration combined with regulatory 
restrictions designed to impede competition. Transparency fosters banking system stability in column (5), where bank system competition is measured by a broader measure of competition from Claessens and Laeven (2004). The result holds in columns (6) through (8) where I account for both macro-economic factors and banking industry structure. Finally, transparency lowers crisis probability controlling for the level of economic development of countries, as a proxy for the overall institutional quality in column (9).

The results in Table 4 broadly support the thesis that greater transparency, reflecting the degree of regulated disclosure, enhances bank system stability via strengthening market discipline. The impact of greater transparency to bank stability is also economically large. To illustrate, based on the complete model estimates in column (8), increasing bank transparency by one standard deviation would lower the likelihood of banking crisis by about 11 percent $^{6}$. This is a significant reduction, given that crisis probabilities are very low at any point in time. Hoggarth and Saport (2001) report the cumulative output loss of the average banking crisis to be about 17 percent of GDP. Applying the crisis-ameliorating probabilities, the impact of greater transparency would be a saving of roughly 1.8 percent of GDP.

With respect to the control variables, confirming economic theory and previous empirical results, improvements in external terms-of-trade reduces crisis probability, while uncontrolled inflation increases probability of banking crisis. As predicted, bank concentration lowers bank crisis probability, confirming the results in Beck et al. (2005). Confirming priors, a banking crisis is less likely in more competitive banking systems. This is consistent with earlier findings (Barth et al., 2004) and Beck et al., 2005) that regulatory restrictions in the areas of entry and banking activity foster bank fragility. It is also confirmed by the direct evidence that increased competitive conduct (or competitiveness) lowers the likelihood of banking crisis which is a new finding in this paper. More developed economies are less likely to suffer systemic banking crisis, indicating the positive role of the overall quality of the institutional environment. In general, the models fit the data well, generating an in-sample correct prediction of crises episodes up to

\footnotetext{
${ }^{6}$ Noting that the predicted value from the model provides an estimate for $\operatorname{Ln}\left(\mathrm{p}_{\mathrm{it}} /\left(1+\mathrm{p}_{\mathrm{it}}\right)\right.$, increasing bank transparency by one standard deviation (i.e. 1), holding the other variables at their mean levels, increases $\operatorname{Ln}\left(\mathrm{p}_{\mathrm{it}} /\left(1+\mathrm{p}_{\mathrm{it}}\right)\right.$ by -2.137 (i.e. $\left.-2.137 \mathrm{X} 1\right)$. Solving for $\mathrm{p}_{\mathrm{it}}$, the probability that banking crisis would occur in country $\mathrm{i}$ during period $\mathrm{t}, \mathrm{p}_{\mathrm{it}}=\mathrm{e}^{-2.137} /\left(1+\mathrm{e}^{-2.137}\right)$, which is equal to 0.1056 .
} 
ninety percent of the time. Note, however, that this high level of fit is within the sample based on which the models are developed, and in no way speaks of their out-of-sample performance.

\section{B. Regulated Disclosure Quality, Private Information Acquisition, Information Dissemination and Banking Crises}

Bank transparency consists of regulated-disclosure quality, information acquisition, and the degree of information dissemination (see Figure 1). Table 5 explores the transparency-stability link further by focusing on the relation between stability and these components of transparency, with a particular focus on the role of regulated disclosure. The table indicates that regulated-disclosure quality (Panel A) and the quality of information dissemination (Panel B) reduce the likelihood of systemic banking crisis; whereas private information acquisition (Panel B) has little role in enhancing banking stability.

Results in column (1) indicate that, controlling for macro-economic sources of instability, the likelihood of banking crisis is lower in countries with greater regulated disclosure quality. Column (2) indicates that, controlling for banking market structure, banking systems with higher regulated disclosure requirements are less vulnerable to crisis. The inverse relation between regulated disclosure and banking system crisis holds in column (3), where I account for both sets of control. Regulated disclosure lowers crisis probability also after controlling for the level of economic development of countries, as a proxy for the overall institutional quality in column (4).

Panel $\mathrm{C}$ indicates that the breadth of information dissemination capability in the country, measured by the degree of media penetration in the economy, has a significant positive impact in fostering banking system stability. In contrast, private information acquisition activities (Panel B) have negligible role to banking stability.

The results also indicate that the control variables act as predicted. The overall effects of bank concentration and bank competition on crisis likelihood are still negative and significant. External terms- 
of-trade improvements reduce, and higher inflation increases crisis probability. In addition, the models fit the data well, correctly identifying episodes of crises, within the sample, up to $95 \%$ of the time.

The results are consistent with the hypothesis that regulated disclosure enhances the stability of a banking system by facilitating market discipline to work via reducing informational asymmetry. The marginal effect of regulated disclosure is also economically meaningful. To provide an idea of the magnitude of this effect, based on the estimates in column (4), we see that an increase in regulated disclosure quality by one standard deviation lowers the likelihood of banking crisis by about 5 percent, which translates into a saving, on average, of about 1 percent of GDP per banking crisis episode.

\section{Regulated Disclosure and Banking Crises: A Closer Look}

Regulated disclosure quality, the focal variable of interest, aggregates the provisions of national banking regulations meant to regulate the comprehensiveness, informativeness, timeliness and credibility of bank generated information. To investigate the impact of regulated disclosure on stability further, Table 6 presents the empirical relations between the components of disclosure quality - disclosure intensity, disclosure informativeness, disclosure timeliness, and disclosure credibility - and crisis probability.

The table clearly indicates that the likelihood of systemic banking crisis is lower in countries with disclosure regulations that require more comprehensive, more informative, more timely, and more credible bank disclosure. Disclosure intensity, the measure of the comprehensiveness of disclosure as required by regulation, is inversely related to crisis probability, and its coefficient is statistically large (column (1)). This is so after controlling for both macroeconomic sources of instability and bank industry structure. The more informative regulatory disclosure is, the less vulnerable the banking system to crisis (column (2)). The more timely regulated disclosure, the less is the likelihood of systemic banking crisis (column (3)). Finally, banking crisis is lower in countries with credible financial reporting as measured by the stringency of external-audit practices across countries. 
Overall, the results are consistent with the "transparency-stability" view that disclosure regulation fosters banking system stability via market discipline. While regulated disclosure and its components are positively related to banking system stability, there is no evidence that it fosters banking crisis. In addition, regulation of disclosure appears to enhance stability by ensuring availability of 'useful' financial information - information that is comprehensive, informative, timely, and credible.

I measure disclosure credibility by the degree of the stringency of external-audit as required by disclosure regulations. I find that this measure is associated with lower likelihood of banking crisis. Disclosure credibility is also negatively related to crisis probability controlling for disclosure intensity (not reported) indicating that stringent auditing is not a mere substitute for accurate and comprehensive disclosure. Rather, regulations that call for more vigilant external audit complement greater disclosure in fostering banking system stability. The finding is consistent with the notion that external audit adds value to market discipline by providing third-party verification of information that banks are reluctant to release to the public voluntarily. In their loan decisions, banks collect private information from their customers. Banks are reluctant to disclose proprietary information about their customers, making it difficult for outsiders, without access to individual loan information, to assess the health of the bank. External auditors have access to bank's individual loans and the banks' risk management practices. By validating through their audit report, external auditors enrich the information environment, allowing investors to assess bank health, and market discipline to work in fostering bank stability.

\section{Robustness Checks}

To ensure accurate inference and avoid mechanical explanations for the main results so far, I provide a series of sensitivity checks in this section. First, in Table 7, I examine the sensitivity of the results to inclusion of variables omitted in the main regressions. I consider both macro-economic (Panel A through C) and institutional variables (Panel D through F). The regression results in all models include all explanatory and control variables in the main regression. To conserve space, I report the coefficients 
of the new variables and the focal variables of interest, those of the transparency and disclosure variables, only.

Economic theory predicts that macro economic shocks that adversely affect the economic performance of bank borrowers, whose impacts cannot be diversified away by the banks, would be positively related to incidence of crises. Among these economic shocks, I include in the main regressions external terms of trade and inflation. Another variable that may capture adverse macro economic shocks that hurt banks via increasing non-performing loans may be the general output downturns related to the business cycle. In Panel A of Table 7, I include a measure of the business cycle, the growth rate in real GDP, in the main regression. The main results that transparency and disclosure reduces crisis probability are robust. Growth in the GDP while having the right sign does not enter significantly.

Bank profitability is partly a function of the costs of funds the bank pays on its deposits. High interest rate could increase the cost of funds for the bank. In addition, high interest rates could increase the default rate of bank borrowers, thus reducing the value of bank assets. To control for the banks cost of funds, I include the short-term real interest rate in the country in Panel B, in addition to the usual control variables. The main results of the paper that bank transparency and disclosure reduces crisis probability remain robust. Real interest rate, while carrying the correct sign in most regressions, does not enter with statistical significance.

The probability of systemic banking crisis can also be affected by the vulnerability of the banking system to sudden capital outflows from the country. In countries particularly with fixed exchange rate regimes, a general lack of confidence by foreign investors, or a mismatch of foreign and local rates of return on investments, may lead to sudden outflows of foreign capital, which could lead to illiquidity at the central bank and banking crisis, when investors convert their local deposits into foreign currency. To control for the potential effects of sudden capital outflows, I include as a variable the ratio of M2 to foreign exchange reserves in Panel C. The variable captures the extent to which the liabilities of the banking system are backed by international reserves. During currency crisis, investors may rush to convert their domestic deposits into foreign currency so that the ratio measures the ability of the central 
bank to meet these demands. Calvo (1996) considers this ratio as a good predictor of a country's vulnerability to balance of payments crises. The main results of the paper are robust to accounting for this variable. Consistent with the theory, external vulnerability as measured by M2 to reserve ratio significantly increases crisis probability.

In addition to macro-economic factors, the main regressions control for the institutional and regulatory environments of the banking sector. As additional robustness, Panel D through F checks for the sensitivity of the main results to other institutional features not controlled for in the regressions. Panel D controls for the features of countries' deposit insurance systems. Demirguc-Kunt et al. (2004) report that explicit deposit insurance increases (weakly) banking instability via exasperating the risk-shifting incentives of banks. To account for this possibility, I include an indicator variable for explicit deposit insurance countries, similar to the way Demirguc-Kunt et al. (2004) did. The results are robust; regulated disclosure, and its properties reduce crisis probability, controlling for the design feature of the banking safety $^{7}$.

Panel E and Panel F explore the impact of the overall institutional environment of banks and bank ownership on bank fragility. In panel E, we include a variable that captures the general openness and competitiveness of the banking system. Consistent with previous findings (e.g., Beck et al., 2005), countries with greater freedom in banking are less likely to experience banking crisis. The main result that transparency and disclosure reduces crisis probability is robust. Panel F accounts for the degree of state ownership in banking. Again, the main results are robust to controlling for the ownership structure in the banking system. There is weak evidence that extensive government ownership of banks is associated with bank fragility.

In addition to the selection of control variables, the research design and the specification of the empirical methodology may influence the reported results. In Table 8, I explore the sensitivity of the results to changes in the research design and methodology. First, in the main regression, a crisis event in a

\footnotetext{
${ }^{7}$ The maximum likelihood iterations fail to converge under reasonable boundary conditions for the specification under column (1). The result is reported for completeness.
} 
country is defined as any year in the sample period, 1990 through 1997 that the country was in crisis. This means that each country is included eight times in a pooled time-series cross section, and the year in which the country was in crisis was coded as a crisis year. Such a design may raise some concerns. The first is that it is very difficult to ascertain the beginning and the end of a crisis episode, and thus the designation of a particular year as a crisis year may not be precise. Second, to the extent that crisis events in contagious years may be correlated, the design may introduce a lack of independence in the error terms. In Panel A and Panel B of Table 8, I test for the robustness of the results for alternative specifications that address these issues.

In Panel A, I define the crisis event more broadly so that if a country experiences a banking crisis in any year between 1990 and 1997, it is considered as a crisis country for the entire sample period. Hence the twenty countries that went through crises were considered as if they experienced crisis in every year of the sample period. Panel A shows that changing the definition of the crisis event in this manner does not affect the main results. The effects of greater bank transparency, regulated-disclosure and the properties of regulated disclosure, such as intensity, informativeness, timeliness and credibility remain negative and highly significant.

In Panel B, I consider a rather narrow definition of the crisis event in that when the crisis period lasts more than a year, I define as the crisis year (event) only the first year of the crisis period and exclude the subsequent crisis years from the analysis. Doing so reduces the sample size considerably, but alleviates the lack-of-independence problem. It has also an advantage of reducing some reverse causality concerns that may arise when a country undergoes multiple years of crisis - the macroeconomic environment in the subsequent years during the crisis period may be influenced by the onset of the crisis. Dropping the subsequent years entirely reduces this type of reverse causality. The impact of bank transparency and regulated-disclosure is unaffected by such a change in the design ${ }^{8}$. Hence, the main results of the paper, the inverse relation between bank transparency and fragility, between regulated-

\footnotetext{
${ }^{8}$ I also run a cross-sectional specification where each county enters only once as a crisis or no-crisis country. The results do not change, though for reasonable parameters the likelihood function fails to converge in some cases.
} 
disclosure quality and fragility, and between the components of disclosure quality - i.e., disclosure intensity, informativeness, timeliness, and credibility - and bank instability are robust to defining the crisis episodes differently.

In addition to the concerns related to the way the crisis event was defined, it might be argued that, because there could be a number of factors that induce banking crisis, the observed result might be a reflection of omitted explanatory variables that are correlated with the transparency variables. The potential variables are too many to feasibly include; and even if it were feasible, the variables would be highly correlated with each other making identification of the effects of any one variable difficult. The main regression controls for the key macro-economic and institutional variables suggested in economic theory. Table 7 above controls for additional variables. However, to effectively address both the potential omitted variables and the problem of lack-of-independence in error terms, Panel $\mathrm{C}$ estimates the original model using a panel data methodology, specifying the latent country-related and time-related sources of variations on the dependent variable, crisis, as random effects. The random-effects panel specification has two advantages: (a) it accounts for intra-country and intra-year correlations in the error terms, and (b) it properly controls for all other non-observable country-related and time-related sources of crisis probability. The model accounts for any omitted country and time factor. Panel C shows that banking system transparency and its components has robust negative impacts on banking fragility.

Finally, the results from the multivariate logistic regression do not explicitly control for the potential for endogeneity. As explained above, I use banking- transparency variables drawn from the period after when we observe the countries' crises experiences. This may raise a concern that the transparency data would reflect the banks' responses to crises episodes, hence introducing reverse causality. If it is true that a country improves its disclosure after a crisis episode, we would expect an occurrence of banking crisis to be followed by improvements in disclosure and transparency - i.e., a positive relation between crisis probability and transparency. Yet, our results so far indicate a robust negative relation between crisis vulnerability and transparency; hence this type of reverse causality appears to be less of a concern. Another form of reverse causality might be the argument that banking 
fragility could lead to lower disclosure and transparency due to fears of greater instability from disclosing bank problems. I can examine the possibility of both forms of reverse causality using instrumental variables to identify the exogenous component of bank transparency and disclosure.

Based on theory and recent empirical works, I use the legal origin of countries as instruments. La Porta et al. (1998) show that civil law countries tend to support government intervention relative to private property rights. To the extent that disclosure regulations are government sanctions, their prevalence and characteristics could be partially dictated by the legal tradition of the country whereas the latter has little effect on the probability of crisis. Legal origin has also been extensively used as an instrument in the finance-growth literature (see Levine, 2003) as well as in the banking crises literature (see, e.g., Barth et al., 2004).

I estimate an instrumental variables model with legal origin as instruments. In the first stage regressions, the data does not reject the validity of the instruments. Panel D presents the instrumental variables results. They confirm the major findings in Table 3 through Table 5 that (i) greater bank transparency lowers the likelihood of systemic banking crisis; and (ii) greater regulated disclosure quality increases the likelihood of banking system stability; and (iii) regulated disclosure that increases disclosure intensity, informativeness, timeliness and credibility fosters banking-system stability. Hence controlling for simultaneity via the instruments does not alter the major findings, suggesting that the results are less likely to be explained by reverse causality of any form.

\section{Conclusion}

The economic value of mandated accounting disclosure is not well understood. Reflecting this broader debate on the value of disclosure, the role of regulated disclosure to banking system stability is also controversial. While the 'transparency-stability' view holds that greater disclosure fosters banking system stability through reducing informational asymmetries, the 'transparency-fragility' view emphasizes the negative externalities that may be associated with greater disclosure and its potential to stymie banking system stability. 
The paper examines the real economic consequences of regulated disclosure - using banking data and the incidence of banking system crises as the real economic variable of interest to measure the economic value of disclosure. Based on data on a cross-section of forty-nine countries in the 1990s, the paper studies the impacts of increased mandated bank disclosure requirements as reflected in the comprehensiveness, informativeness, timeliness and credibility of bank disclosure on the likelihood of suffering systemic banking crisis.

The study documents that mandated disclosure is strongly associated with banking system stability. Specifically, the likelihood of systemic banking crisis is lower in countries with regulations that require (i) more comprehensive, (ii) more informative, (iii) more timely; and (iv) more credible of bank disclosure. The results are consistent with theories that emphasize informational asymmetry as a rational for public regulation of disclosure and those that envision positive externalities from disclosure regulations.

The impact of greater banking disclosure and the consequent transparency to banking stability is economically large. The results indicate that greater disclosure results in significant savings in countries' output loss that is often associated with banking system instability. 


\section{References}

Admati, A., Pfleiderer P., 2000. Forcing firms to talk: financial disclosure regulation and externalities. The Review of Financial Studies 13, 479-519.

Alford, A., Jones, J., Leftwich R., Zmijewski, M., 1993. Relative informativeness of accounting disclosures in different countries. Journal of Accounting Research Supplement, 183-223.

Ali, A., Hwang, L., 2000. Country-specific factors related to financial reporting and the value relevance of accounting data. Journal of Accounting Research 38, 1-21.

Ball, R., Kothari, S.P., Robin A., 2000. The effect of international institutional factors on properties of accounting earnings. Journal of Accounting and Economics 29, 1-51.

Baumann, U., Nier E., 2004. Disclosure, volatility, and transparency: an empirical investigation into the value of bank disclosure. Economic Policy Review (Federal Reserve Bank of New York) 10, 31-45.

Barth, J. R., Caprio, G., Levine, R., 2001. The regulation and supervision of banks around the world: A new database, In: Brookings-Wharton Papers on Financial Services, Robert E. Litan and Richard Herring, (Eds.), Washington, DC: Brookings Institution Press, pp 183-240.

Barth, J. R., Caprio, G., Levine, R., 2004. Bank supervision and regulation: what works best?’ Journal of Financial Intermediation 13, 205-48.

Beck, T., Demirguc-Kunt, A., Levine, R., 2005. Bank concentration, competition and crises: First results. Journal of Banking and Finance, forthcoming.

Benston, G., 1969. The value of the SEC's accounting disclosure requirements. The Accounting Review $54,515-532$.

Benston, G., 1934. Required disclosure and the stock market: An evaluation of the Securities Exchange Act of 1934. The American Review 63, 132-155.

Bernanke, B. and Gertler, M., 1990. Financial fragility and economic performance. Quarterly Journal of Economics 105, 87-114.

Bhattacharya, U., Daouk, H., Welker, M., 2003. The world price of earnings opacity. The Accounting Review 78, 641-678.

Diamond, D. and Dybvig, P., 1983. "Bank Runs, Deposit Insurance and Liquidity.” Journal of Political Economy 91, 401-19.

Bryant, J., 1980. A model of reserves, bank runs and deposit insurance. Journal of Banking and Finance $43,749-61$.

Bushman, R., Piotroski, J., Smith, A., 2005. Insider trading restrictions and analyst's incentives to follow firms. Journal of Finance 60, 1-35.

Bushman, R., Piotroski, J., Smith, A., 2004. What determines corporate transparency? Journal of Accounting Research 42, 207-52.

Bushman, R., Smith, A., 2001. Financial accounting information and corporate Governance. Journal of Accounting and Economics 31, 237-333. 
Calvo, G.A., 1996. Capital flows and macroeconomic management: tequila lessons. International Journal of Finance and Economics 1, 207-34.

Calomiris, W., Mason, J.R., 1997. Contagion and bank failures during the great depression: The June 1932 Chicago banking panic.” American Economic Review 87, 863-83.

Center for International Analysis and Research (CIFAR), 1995. International Accounting and Auditing Trends, $4^{\text {th }}$ Edition, CIFAR publications Inc., Princeton, NJ.

Claessens, S., Laeven, L., 2004. What drives bank competition? some international evidence. Journal of Money, Credit and Banking 36, 563-84.

Coffee, J., 1984. Market failure and the economic case for a mandatory disclosure system.” Virginia Law Review 70, 717-753.

Core, J., 2001. A review of the empirical disclosure literature: discussion. Journal of Accounting and Economics 31, 441-456.

Cull, R., Senbet L., Sorge, M., 2005. Deposit insurance and financial development. Journal of Money, Credit and Banking 37, 43-82.

Demirguc-Kunt, A., Detragiache. E., 2005. Cross-country empirical studies of systemic bank distress: a survey. National Institute Economic Review 192, 68-83.

Demirguc-Kunt, A., Detragiache. E., 2004. Market discipline and deposit insurance.” Journal of Monetary Economics 51, 375-99.

Dye, R., 1989. Mandatory versus voluntary disclosure: the case of financial and real externalities. The Accounting Review 65, 1-24.

Fishman, M., Hagerty, K., 1989. Disclosure decisions by firms and the competition for price efficiency. Journal of Finance 44, 633-46.

Francis, J., Khurana I., Pereira, R., 2003. The role of accounting and auditing in corporate governance and the development of financial markets around the world. Asia-Pacific Journal of Accounting and Economics 10, 1-30.

Fields, T., T. Lys, T., Vincent, L., 2001. Empirical research on accounting choice. Journal of Accounting and Economics 31, 255-308.

Guenther, D., Young, D., 2000. The Association between financial accounting measures and real economic activity: A multinational study. Journal of Accounting and Economics 29, 53-72.

Gilbert, R.,Vaughan, M.D., 1998. Does the publication of supervisory enforcement actions add to market eiscipline? Research in Financial Services: Private and Public Policy 10, 259-280.

Healy, P., Palepu, K., 2001. Information asymmetry, corporate disclosure, and the capital markets: A review of the empirical disclosure literature. Journal of Accounting and Economics 31, 405-440.

Hoggarth, G., Saporta, V., 2001. Costs of banking system instability: some empirical evidence. Financial Stability Review, 148-165.

Hope, O., 2003. Disclosure practices, enforcement of accounting standards and analyst forecast accuracy: An international study. Journal of Accounting Research 41, 235-72. 
Jaggi, B., Low, P., 2000. Impact of culture, market forces, and legal system on financial disclosures. The International Journal of Accounting 35, 495-519.

Kaufman, G., 1994. Bank contagion: A review of theory and evidence. Journal of Financial Services Research 8, 123-50.

Kaminsky, G., Reinhart, C., 1999. The twin crises: the causes of banking and balance of payment problems. American Economic Review 89, 473-500.

Kothari, S. P., 2001. Capital markets research in accounting. Journal of Accounting and Economics 31, 105-231.

Land, J., Lang, M., 2003. Empirical evidence on the evolution of international earnings.

The Accounting Review 77, 115-33.

Leftwich, R., 1980. Market failure fallacies and accounting information. Journal of Accounting and Economics 2, 193-211.

Leuz, C., Nanda, D., and Wysocki, P., 2003. Earnings management and institutional factors: an international comparison. Journal of Financial Economics 69, 505-27.

Mankiw, G. 1986. The Allocation of credit and financial collapse. Quarterly Journal of Economics 101, 455-70.

Miron, J. A., 1986. Financial panics, the seasonality of the nominal interest rate, and the founding of the fed. American Economic Review 76, 25-40.

Panzar, J. C., Rosse, J.N., 1986. Testing for 'Monopoly' equilibrium. Journal of Industrial Economics 35, $443-456$.

Stigler, G., 1964. Public regulation of the securities markets. Journal of Business 37, 117-142.

Watts, R. and J. Zimmerman, 1986. Positive Accounting Theory, Printice-Hall, Englewood Cliffs, NJ

World Bank, 1999. World Development Indicators, Washington DC.

World Bank, 2003. Database on Episodes of Systemic and Borderline Financial Crises, Washington DC. 


\section{Table 1: Summary Statistics}

\begin{tabular}{|l|c|c|c|c|c|}
\hline Variable & N & Mean & Std Dev & Minimum & Maximum \\
\hline Crisis & 392 & 0.170 & 0.397 & 0 & 1.000 \\
\hline Bank Transparency & 232 & $7.9 \mathrm{E}-17$ & 1.000 & -2.522 & 1.480 \\
Regulated Disclosure Quality & 360 & $-2.14 \mathrm{E}-14$ & 1.000 & -2.990 & 1.259 \\
Private Information Acquisition & 256 & 11.654 & 8.141 & 0 & 32.400 \\
Information Dissemination & 256 & 70.763 & 21.958 & 23.050 & 96.720 \\
Disclosure Intensity & 376 & 0.274 & 0.869 & -1.917 & 1.342 \\
Disclosure Informativeness & 368 & 0.009 & 1.002 & -3.505 & 0.565 \\
Disclosure Timeliness & 256 & 65.28 & 25.54 & 17.39 & 99.28 \\
Disclosure Credibility & 392 & 0.024 & 1.124 & -6.725 & 0.554 \\
\hline Bank Competition & 282 & 0.653 & 0.105 & 0.410 & 0.920 \\
Bank Concentration & 392 & 0.715 & 0.219 & 0.190 & 1.000 \\
External Terms of Trade & 383 & 0.024 & 0.092 & -0.189 & 0.232 \\
Log of average Inflation & 323 & 0.115 & 0.102 & 0.010 & 0.460 \\
Per capita GDP & 392 & 8.428 & 1.661 & 5.000 & 10.779 \\
\hline
\end{tabular}


Table 2: Bank Transparency and Disclosure across Countries

\begin{tabular}{|c|c|c|c|c|c|c|c|c|}
\hline & $\begin{array}{l}\text { Bank } \\
\text { Transparency } \\
\end{array}$ & $\begin{array}{l}\text { Regulated } \\
\text { Disclosure } \\
\text { Quality } \\
\end{array}$ & $\begin{array}{l}\text { Private } \\
\text { Information. } \\
\text { Acquisition } \\
\end{array}$ & $\begin{array}{l}\text { Information. } \\
\text { Dissemination }\end{array}$ & $\begin{array}{l}\text { Disclosure } \\
\text { Intensity } \\
\end{array}$ & $\begin{array}{l}\text { Disclosure } \\
\text { Timeliness } \\
\end{array}$ & $\begin{array}{l}\text { Disclosure } \\
\text { Informativeness } \\
\end{array}$ & $\begin{array}{l}\text { Disclosure } \\
\text { Credibility } \\
\end{array}$ \\
\hline \multicolumn{9}{|c|}{ Countries with No Systemic Banking Crisis in 1990 - 1997} \\
\hline Australia & 0.191 & -0.431 & 12.73 & 68.29 & 0.083 & 91.3 & -1.593 & 0.554 \\
\hline Austria & -0.440 & -0.675 & 8.63 & 87.53 & -1.049 & 68.12 & 0.564 & 0.554 \\
\hline Bahrain & & 1.118 & & & 1.342 & & 0.565 & 0.554 \\
\hline Belgium & 0.198 & -0.913 & 15.33 & 86.73 & 0.210 & 63.04 & -1.593 & 0.554 \\
\hline Botswana & & 0.379 & & & 0.210 & . & 0.565 & 0.029 \\
\hline Burundi & & 0.972 & & & 1.342 & & 0.565 & -0.655 \\
\hline Canada & 1.337 & 1.259 & 16.9 & 93.37 & 1.342 & 99.28 & 0.565 & 0.029 \\
\hline Chile & -0.229 & 0.511 & 5.53 & 62.46 & 0.210 & 94.2 & 0.565 & 0.554 \\
\hline Denmark & 0.166 & 0.124 & 12.87 & 95.52 & 0.210 & 73.91 & 0.565 & 0.554 \\
\hline Egypt & & 0.442 & r & & 0.210 & . & 0.565 & 0.554 \\
\hline El Salvador & & 0.442 & & & 0.210 & & 0.565 & 0.554 \\
\hline France & 0.627 & -0.612 & 23.2 & 86.14 & 0.210 & 78.26 & -1.593 & 0.554 \\
\hline Germany & 0.861 & -0.810 & 32.4 & 90.99 & 0.210 & 68.12 & -1.593 & 0.554 \\
\hline Ghana & & -2.008 & & & -1.917 & & -1.348 & 0.554 \\
\hline Greece & & & 6.1 & 72.07 & 0.210 & 17.39 & & 0.029 \\
\hline Guatemala & & -2.178 & 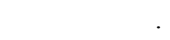 & & -1.917 & . & -1.348 & -0.655 \\
\hline Honduras & & -1.276 & & & -0.658 & & -1.348 & 0.554 \\
\hline Ireland & 0.006 & 0.641 & 5.43 & 88.34 & 1.342 & 69.57 & 0.565 & 0.554 \\
\hline Israel & 0.385 & 0.638 & 3.19 & 82.47 & 1.342 & 66.67 & 0.565 & -0.131 \\
\hline Lesotho & & -0.460 & . & & -1.049 & $\cdot$ & 0.565 & -0.655 \\
\hline Nepal & & & & & & & & 0.554 \\
\hline Pakistan & -1.173 & 0.323 & 3.4 & 32.47 & 0.210 & 51.45 & 0.565 & 0.554 \\
\hline Philippines & -0.167 & 0.849 & 10.87 & 44.26 & 1.342 & 75.36 & 0.565 & -0.655 \\
\hline Portugal & -0.456 & -0.016 & 5.33 & 70.59 & 0.210 & 62.32 & 0.565 & -0.655 \\
\hline Singapore & 0.900 & 0.528 & 20.9 & 83.72 & 1.342 & 63.77 & 0.565 & 0.554 \\
\hline $\begin{array}{l}\text { Switzerland } \\
\text { United }\end{array}$ & 1.112 & 0.726 & 19.97 & 93.78 & 1.342 & 73.91 & 0.565 & 0.554 \\
\hline Kingdom & 1.272 & 1.031 & 20.1 & 90.81 & 1.342 & 86.96 & 0.565 & -0.131 \\
\hline United States & 1.488 & 0.582 & 30.23 & 96.72 & 0.210 & 97.83 & 0.565 & 0.554 \\
\hline Zambia & & 0.342 & & & 0.210 & $\cdot$ & 0.565 & 0.554 \\
\hline Average & 0.358 & 0.060 & 14.0616667 & 79.23667 & 0.296 & 72.30333 & 0.0327 & 0.2440 \\
\hline \multicolumn{9}{|c|}{ Countries with Systemic Banking Crisis in 1990 - 1997} \\
\hline Finland & 1.049 & 0.867 & 14.9 & 94.82 & 1.342 & 78.99 & 0.565 & 0.029 \\
\hline Guyana & & 0.346 & & & 0.210 & & 0.565 & -0.13 \\
\hline India & -1.423 & -1.571 & 11.9 & 29.51 & -0.658 & 45.65 & -1.348 & 0.131 \\
\hline Indonesia & & 0.368 & & & 0.210 & & 0.565 & 0.554 \\
\hline Italy & 0.773 & 0.737 & 21.57 & 78.98 & 1.342 & 86.96 & -1.593 & -6.725 \\
\hline Jamaica & & 0.442 & & & 0.210 & & 0.565 & 0.554 \\
\hline Japan & 0.977 & 0.633 & 14.87 & 91.79 & 0.210 & 86.23 & 0.565 & -3.075 \\
\hline Jordan & & 0.442 & & & 0.210 & & 0.565 & 0.554 \\
\hline Kenya & -2.522 & -2.990 & 0 & 23.05 & -0.658 & 17.39 & -3.506 & 0.554 \\
\hline Korea & & & 9.9 & 83.5 & 1.341 & 17.39 & & -0.131 \\
\hline Malaysia & -0.100 & -0.054 & 19.9 & 63.83 & 0.210 & 65.22 & 0.565 & 0.554 \\
\hline Mauritania & & 0.442 & & & 0.210 & & 0.565 & 0.554 \\
\hline Mexico & -0.233 & -0.297 & 18.53 & 59.95 & -1.049 & 84.78 & 0.565 & -0.131 \\
\hline Nigeria & -1.707 & -0.924 & 0 & 27.29 & 0.210 & 17.39 & 0.565 & -0.262 \\
\hline Peru & -0.225 & 0.074 & 8.1 & 40.33 & 0.210 & 71.74 & 0.565 & 0.554 \\
\hline Sri Lanka & -0.591 & 0.724 & 2.4 & 37.86 & 1.342 & 73.91 & 0.565 & 0.554 \\
\hline Sweden & & & 20.6 & 95.47 & & 86.23 & 0.565 & 0.029 \\
\hline Thailand & -0.238 & -0.723 & 9.77 & 52.26 & -0.658 & 89.13 & -1.348 & -0.131 \\
\hline Turkey & -1.381 & -1.802 & 7.97 & 58.55 & 0.210 & 17.39 & -1.593 & 0.554 \\
\hline Venezuela & & 0.442 & - & & 0.210 & . & 0.565 & 0.554 \\
\hline Average & -0.468 & -0.158 & 11.46 & 59.80 & 0.245 & 59.886 & -0.078 & -0.243 \\
\hline $\begin{array}{l}\text { Differences } \\
\text { [p-values of] }\end{array}$ & $0.011^{b}$ & 0.232 & 0.193 & $0.009^{\mathrm{a}}$ & 0.421 & $0.083^{\mathrm{c}}$ & 0.361 & $0.077^{\mathrm{C}}$ \\
\hline
\end{tabular}

\footnotetext{
${ }^{\mathrm{a}}$ significant at $1 \%{ }^{\mathrm{b}}$ significant at $5 \%{ }^{\mathrm{c}}$ significant at $10 \%$
} 
Table 3: Correlations

\begin{tabular}{|c|c|c|c|c|c|c|c|c|c|c|c|c|c|}
\hline & Crisis & $\begin{array}{c}\text { Bank } \\
\text { Transparency }\end{array}$ & $\begin{array}{l}\text { Regulated } \\
\text { Disclosure } \\
\text { Quality }\end{array}$ & $\begin{array}{c}\text { Private } \\
\text { Information } \\
\text { Acquisition }\end{array}$ & $\begin{array}{l}\text { Information } \\
\text { Dissemination }\end{array}$ & $\begin{array}{l}\text { Disclosure } \\
\text { Intensity }\end{array}$ & $\begin{array}{l}\text { Disclosure } \\
\text { Informativeness }\end{array}$ & $\begin{array}{l}\text { Disclosure } \\
\text { Timeliness }\end{array}$ & $\begin{array}{l}\text { Disclosure } \\
\text { Credibility }\end{array}$ & $\begin{array}{c}\text { Bank } \\
\text { Concentration }\end{array}$ & $\begin{array}{c}\text { Bank } \\
\text { Competition }\end{array}$ & $\begin{array}{c}\text { External } \\
\text { Terms of } \\
\text { Trade }\end{array}$ & Inflation \\
\hline \multirow[t]{2}{*}{ Bank Transparency } & -0.124 & & & & & & & & & & & & \\
\hline & $(0.056)$ & & & & & & & & & & & & \\
\hline \multirow{2}{*}{$\begin{array}{l}\text { Regulated } \\
\text { Disclosure Quality }\end{array}$} & -0.059 & 0.813 & & & & & & & & & & & \\
\hline & $(0.361)$ & $(<.0001)$ & & & & & & & & & & & \\
\hline \multirow{2}{*}{$\begin{array}{l}\text { Private Information } \\
\text { Acquisition }\end{array}$} & 0.016 & 0.858 & 0.457 & & & & & & & & & & \\
\hline & $(0.777)$ & $(<.0001)$ & $(<.0001)$ & & & & & & & & & & \\
\hline \multirow{2}{*}{$\begin{array}{l}\text { Information } \\
\text { Dissemination }\end{array}$} & -0.084 & 0.829 & 0.553 & 0.630 & & & & & & & & & \\
\hline & $(0.144)$ & $(<.0001)$ & $(<.0001)$ & $(<.0001)$ & & & & & & & & & \\
\hline \multirow{2}{*}{$\begin{array}{l}\text { Disclosure } \\
\text { Intensity }\end{array}$} & -0.0073 & 0.601 & 0.779 & 0.315 & 0.402 & & & & & & & & \\
\hline & $(0.8885)$ & $(<.0001)$ & $(<.0001)$ & $(<.0001)$ & $(<.0001)$ & & & & & & & & \\
\hline \multirow{2}{*}{$\begin{array}{l}\text { Disclosure } \\
\text { Informativeness }\end{array}$} & -0.0286 & 0.351 & 0.640 & 0.062 & 0.308 & 0.1229 & & & & & & & \\
\hline & $(0.888)$ & $(<.0001)$ & $(<.0001)$ & $(0.323)$ & $(<.0001)$ & $(0.018)$ & & & & & & & \\
\hline \multirow{2}{*}{$\begin{array}{l}\text { Disclosure } \\
\text { Timeliness }\end{array}$} & -0.0054 & 0.803 & 0.756 & 0.575 & 0.443 & 0.2719 & 0.3704 & & & & & & \\
\hline & $(0.575)$ & $(<.0001)$ & $(<.0001)$ & $(<.0001)$ & $(<.0001)$ & $(0.0001)$ & $(0.0001)$ & & & & & & \\
\hline \multirow{2}{*}{$\begin{array}{l}\text { Disclosure } \\
\text { Credibility }\end{array}$} & -0.2667 & -0.217 & 0.280 & -0.069 & -0.099 & --0.084 & 0.1387 & -0.1837 & & & & & \\
\hline & $(<0.0001)$ & $(0.001)$ & $(<.0001)$ & $(0.254)$ & $(0.101)$ & $(0.073)$ & $(0.0058)$ & $(0.002)$ & & & & & \\
\hline \multirow{2}{*}{$\begin{array}{l}\text { Bank } \\
\text { Concentration }\end{array}$} & 0.0537 & -0.100 & 0.011 & -0.117 & 0.071 & 0.05404 & 0.3231 & -0.0844 & 0.29267 & & & & \\
\hline & $(0.2041)$ & $(0.121)$ & $(0.863)$ & $(0.041)$ & $(0.217)$ & $(0.2999)$ & $(0.0001)$ & $(0.1416)$ & $(<.0001)$ & & & & \\
\hline \multirow[t]{2}{*}{ Bank Competition } & -0.2634 & 0.163 & 0.157 & 0.093 & 0.060 & 0.00250 & 0.1854 & 0.0866 & 0.15144 & 0.41617 & & & \\
\hline & $(<.0001)$ & $(0.022)$ & $(0.027)$ & $(0.160)$ & $(0.361)$ & $(0.9709)$ & $(0.005)$ & $(0.1966)$ & $(0.0234)$ & $(<.0001)$ & & & \\
\hline \multirow{2}{*}{$\begin{array}{l}\text { External Terms of } \\
\text { Trade }\end{array}$} & 0.02583 & -0.569 & -0.490 & -0.276 & -0.459 & -0.30211 & -0.2734 & -0.1448 & 0.03622 & -0.06772 & -0.01916 & & \\
\hline & $(0.6144)$ & $(<.0001)$ & $(<.0001)$ & $(<.0001)$ & $(<.0001)$ & $(<.0001)$ & $(0.0001)$ & $(0.0153)$ & $(0.5293)$ & $(0.1860)$ & $(0.7755)$ & & \\
\hline \multirow[t]{2}{*}{ Inflation } & 0.01597 & -0.094 & -0.120 & -0.134 & -0.227 & -0.37016 & -0.0925 & -0.5021 & 0.20828 & 0.09893 & 0.29594 & -0.01223 & \\
\hline & $(0.7432)$ & $(0.316)$ & $(0.198)$ & $(0.105)$ & $(0.006)$ & $(<.0001)$ & $(0.1118)$ & $(0.0001)$ & $(0.0002)$ & $(0.0420)$ & $(<.0001)$ & $(0.8153)$ & \\
\hline \multirow[t]{2}{*}{ Per Capita GDP } & -0.13094 & 0.809 & 0.546 & 0.611 & 0.962 & 0.42028 & 0.1527 & 0.48889 & -0.12436 & -0.25521 & -0.05737 & -0.30561 & -0.52670 \\
\hline & $(0.0069)$ & $(<.0001)$ & $(<.0001)$ & $(<.0001)$ & $(<.0001)$ & $(<.0001)$ & $(0.0024)$ & $(0.0001)$ & $(0.0110)$ & $(<.0001)$ & $(0.3844)$ & $(<.0001)$ & $(<.0001)$ \\
\hline
\end{tabular}


Table 4: Bank Transparency \& Banking System Crisis

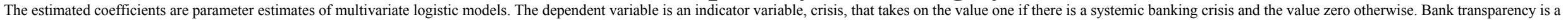

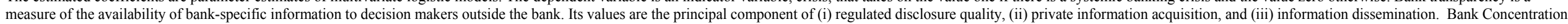

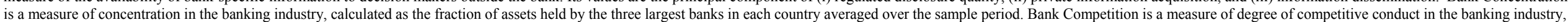

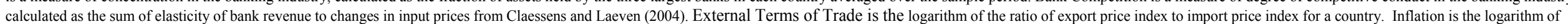

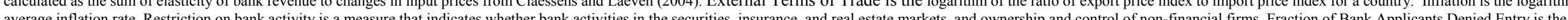

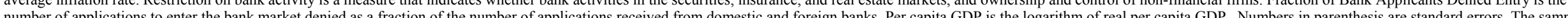
period is 1990 through 1997. Detailed variable definitions are given in Appendix II.

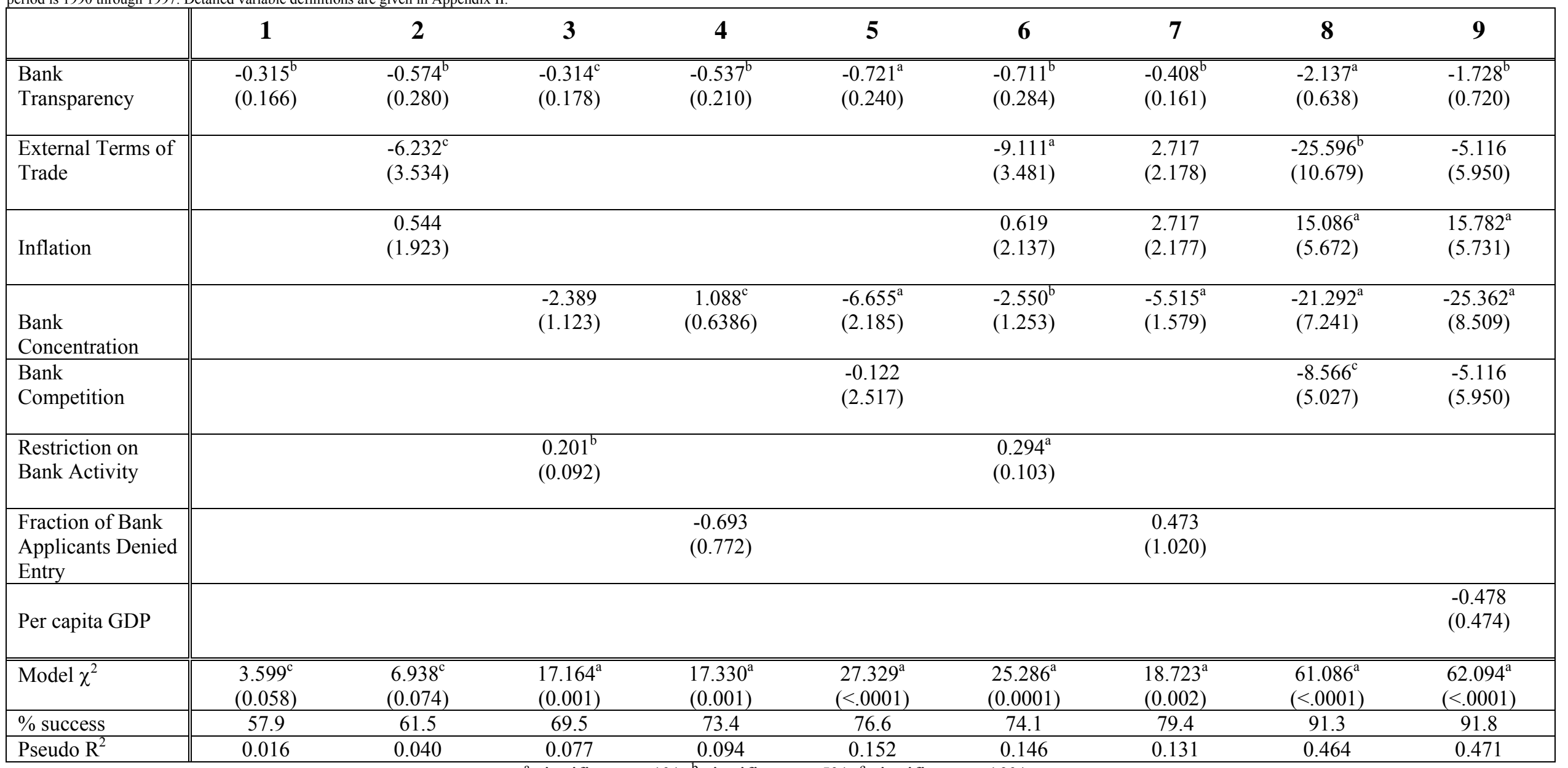

${ }^{a}$ significant at $1 \% ;{ }^{b}$ significant at $5 \% ;{ }^{c}$ significant at $10 \%$ 
Table 5: Bank Reporting Quality, Private Information Acquisition, Information Dissemination \& Banking Crisis

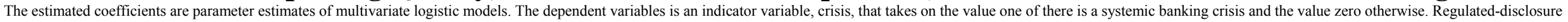

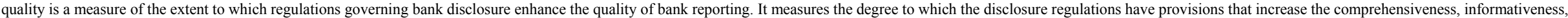

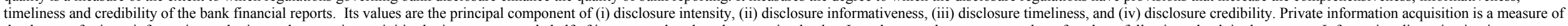

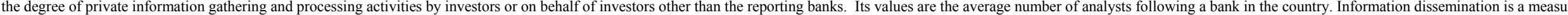

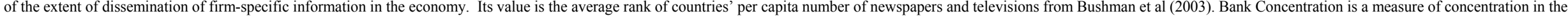

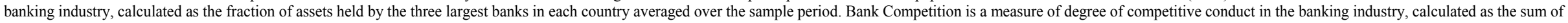

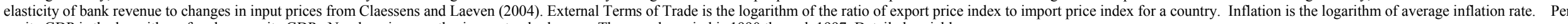
capita GDP is the logarithm of real per capita GDP. Numbers in parenthesis are standard errors. The sample period is 1990 through 1997. Detailed variable

definitions are given in Appendix II.

\begin{tabular}{|c|c|c|c|c|c|c|c|c|}
\hline & \multicolumn{4}{|c|}{ Panel A } & \multicolumn{2}{|c|}{ Panel B } & \multicolumn{2}{|c|}{ Panel C } \\
\hline & 1 & 2 & 3 & 4 & 5 & 6 & 7 & 8 \\
\hline $\begin{array}{l}\text { Regulated- } \\
\text { Disclosure } \\
\text { Quality }\end{array}$ & $\begin{array}{l}-0.503^{b} \\
(0.238)\end{array}$ & $\begin{array}{l}-0.505^{\mathrm{b}} \\
(0.216)\end{array}$ & $\begin{array}{l}-2.893^{\mathrm{a}} \\
(0.788)\end{array}$ & $\begin{array}{l}-6.638^{\mathrm{a}} \\
(2.435)\end{array}$ & & & & \\
\hline $\begin{array}{l}\text { Information } \\
\text { Acquisition }\end{array}$ & & & & & $\begin{array}{l}-0.115 \\
(0.261)\end{array}$ & $\begin{array}{l}-0.190 \\
(0.206)\end{array}$ & & \\
\hline $\begin{array}{l}\text { Information } \\
\text { Dissemination }\end{array}$ & & & & & & & $\begin{array}{l}-0.005 \\
(0.011)\end{array}$ & $\begin{array}{l}-2.006^{\mathrm{a}} \\
(0.682)\end{array}$ \\
\hline $\begin{array}{l}\text { External Terms of } \\
\text { Trade }\end{array}$ & $\begin{array}{l}-6.004^{\mathrm{c}} \\
(3.442)\end{array}$ & & $\begin{array}{l}-30.538^{a} \\
(10.933)\end{array}$ & $\begin{array}{l}-58.815^{\mathrm{a}} \\
(21.407)\end{array}$ & $\begin{array}{l}-0.950 \\
(3.708)\end{array}$ & $\begin{array}{l}-2.768 \\
(3.715)\end{array}$ & $\begin{array}{l}-0.989 \\
(3.697)\end{array}$ & $\begin{array}{l}-3.990 \\
(3.726)\end{array}$ \\
\hline Inflation & $\begin{array}{c}1.279 \\
(1.740)\end{array}$ & & $\begin{array}{l}15.242^{\mathrm{a}} \\
(4.913)\end{array}$ & $\begin{array}{c}30.668^{\mathrm{b}} \\
(11.981)\end{array}$ & $\begin{array}{c}6.175^{\mathrm{b}} \\
(2.218)\end{array}$ & $\begin{array}{l}5.288^{b} \\
(2.390)\end{array}$ & $\begin{array}{l}6.661^{b} \\
(2.681)\end{array}$ & $\begin{array}{l}9.326^{\mathrm{a}} \\
(2.820)\end{array}$ \\
\hline $\begin{array}{l}\text { Bank } \\
\text { Concentration }\end{array}$ & & $\begin{array}{l}-5.297^{\mathrm{a}} \\
(1.921)\end{array}$ & $\begin{array}{r}-14.946^{\mathrm{a}} \\
(4.511)\end{array}$ & $\begin{array}{l}-7.413^{b} \\
(3.570)\end{array}$ & $\begin{array}{l}-0.888 \\
(1.512)\end{array}$ & $\begin{array}{l}-1.407 \\
(1.656)\end{array}$ & $\begin{array}{l}-1.008 \\
(1.471)\end{array}$ & $\begin{array}{l}-1.117 \\
(1.547)\end{array}$ \\
\hline Bank Competition & & $\begin{array}{l}-0.883 \\
(2.429)\end{array}$ & $\begin{array}{l}-16.946^{b} \\
(7.152)\end{array}$ & $\begin{array}{l}-48.559^{b} \\
(20.322)\end{array}$ & $\begin{array}{l}-11.206^{\mathrm{a}} \\
(3.116)\end{array}$ & $\begin{array}{c}-10.178^{\mathrm{a}} \\
(3.058)\end{array}$ & $\begin{array}{l}-11.500^{\mathrm{a}} \\
(3.105)\end{array}$ & $\begin{array}{l}-13.183^{\mathrm{a}} \\
(3.293)\end{array}$ \\
\hline Per capita GDP & & & & $\begin{array}{c}2.056 \\
(1.138)\end{array}$ & & $\begin{array}{c}0.094 \\
(0.338)\end{array}$ & & $\begin{array}{l}0.126^{\mathrm{a}} \\
(0.045)\end{array}$ \\
\hline Model $\chi^{2}$ & $\begin{array}{l}7.070^{\mathrm{c}} \\
(0.070) \\
\end{array}$ & $\begin{array}{l}22.711^{\mathrm{a}} \\
(<.0001)\end{array}$ & $\begin{array}{l}73.373^{\mathrm{a}} \\
(<.0001) \\
\end{array}$ & $\begin{array}{l}76.929^{\mathrm{a}} \\
(<.0001)\end{array}$ & $\begin{array}{l}29.870^{\mathrm{a}} \\
(<.0001)\end{array}$ & $\begin{array}{c}31.310^{\mathrm{a}} \\
(<.0001)\end{array}$ & $\begin{array}{c}29.864^{\mathrm{a}} \\
(<.0001)\end{array}$ & $\begin{array}{l}43.469^{\mathrm{a}} \\
(<.0001)\end{array}$ \\
\hline$\%$ success & 59.1 & 73.6 & 94.3 & 94.8 & 81.9 & 81.1 & 81.9 & 89.7 \\
\hline Pseudo $\mathrm{R}^{2}$ & 0.041 & 0.127 & 0.557 & 0.584 & 0.192 & 0.208 & 0.192 & 0.288 \\
\hline
\end{tabular}

${ }^{\text {a }}$ significant at $1 \% ;{ }^{b}$ significant at $5 \% ;{ }^{c}$ significant at $10 \%$ 


\section{Table 6: Disclosure Intensity, Informativeness, Timeliness, Credibility and Banking Crises}

The estimated coefficients are parameter estimates of multivariate logistic models. The dependent variable is an indicator variable, crisis, that takes on the value one if there is a systemic banking crisis and the value zero otherwise. Disclosure intensity is a measure of the extent and comprehensiveness of financial reporting required of banks. Its values are the principal component of four indicator variables: (i) Presentation of Non-Performing Loans - a variable that takes 1 if bank regulation requires that accrued income on non-performing loans should not be reported; (ii) Reporting Consolidated Financial Statements - a variable that takes 1 if consolidated financial statements of bank and non-bank subsidiaries are required; (iii) Reporting Off-Balance-Sheet to the Public - a variable that takes 1 if off balance sheet items are required to be disclosed to the public; and (iv) Reporting Risk Management Practice - a variable that takes 1 if banks are required to disclose risk management practices to the public. Disclosure informativeness is a measure of the degree to which bank disclosure accurately represents banks' financial condition. Its values are the principal components of the indicator variables in (i) and (ii) above. Disclosure timeliness is a measure of the bank disclosure is made on timely basis. Its value is an index of the average frequency and comprehensiveness of interim financial reports. Disclosure credibility is a measure of the degree to which external audits are independent, professional and rigorous as reflected in bank regulations governing audit practices. Bank Concentration is a measure of concentration in the banking industry, calculated as the fraction of assets held by the three largest banks in each country averaged over the sample period. Bank Competition is a measure of degree of competitive conduct in the banking industry, calculated as the sum of elasticity of bank revenue to changes in input prices from Claessens and Laeven (2004). External Terms of Trade is the logarithm of the ratio of export price index to import price index for a country. Inflation is the logarithm of average inflation rate. Per capita GDP is the logarithm of real per capita GDP. Numbers in parenthesis are standard errors. The sample period is 1990 through 1997. Detailed variable definitions are given in Appendix II.

\begin{tabular}{|c|c|c|c|c|}
\hline & 1 & 2 & 3 & 4 \\
\hline Bank Concentration & $\begin{array}{l}-8.095^{\mathrm{b}} \\
(3.212)\end{array}$ & $\begin{array}{c}-13.276^{\mathrm{a}} \\
(4.372)\end{array}$ & $\begin{array}{c}-1.927 \\
(1.592)\end{array}$ & $\begin{array}{c}-19.342^{\mathrm{b}} \\
(7.809)\end{array}$ \\
\hline Bank Completion & $\begin{array}{c}-19.735^{\mathrm{a}} \\
(7.188)\end{array}$ & $\begin{array}{l}-9.634^{\mathrm{a}} \\
(3.195)\end{array}$ & $\begin{array}{c}-11.455^{\mathrm{a}} \\
(3.443)\end{array}$ & $\begin{array}{c}-10.806^{\mathrm{a}} \\
(3.933)\end{array}$ \\
\hline External Terms of Trade & $\begin{array}{c}-23.229^{\mathrm{a}} \\
(6.280)\end{array}$ & $\begin{array}{c}-13.972^{\mathrm{a}} \\
(4.098)\end{array}$ & $\begin{array}{l}-5.130 \\
(4.292)\end{array}$ & $\begin{array}{l}-6.652^{\mathrm{c}} \\
(3.500)\end{array}$ \\
\hline Inflation & $\begin{array}{l}12.688^{\mathrm{a}} \\
(4.517)\end{array}$ & $\begin{array}{l}14.255^{\mathrm{a}} \\
(4.436)\end{array}$ & $\begin{array}{l}5.511^{\mathrm{b}} \\
(2.531)\end{array}$ & $\begin{array}{l}20.377^{\mathrm{a}} \\
(7.601)\end{array}$ \\
\hline Disclosure Intensity & $\begin{array}{l}-4.219^{\mathrm{a}} \\
(1.129)\end{array}$ & & & \\
\hline Disclosure Informativeness & & $\begin{array}{l}-0.826^{b} \\
(0.424)\end{array}$ & & \\
\hline Disclosure Timeliness & & & $\begin{array}{l}-0.025^{\mathrm{c}} \\
(0.014)\end{array}$ & \\
\hline Disclosure Credibility & & & & $\begin{array}{l}-0.985^{\mathrm{a}} \\
(0.372)\end{array}$ \\
\hline Per Capita GDP & $\begin{array}{c}-0.263 \\
(0.263)\end{array}$ & $\begin{array}{l}-0.491^{b} \\
(0.253)\end{array}$ & $\begin{array}{c}0.045 \\
(0.206)\end{array}$ & $\begin{array}{l}-1.449^{\mathrm{a}} \\
(0.538)\end{array}$ \\
\hline Model $\chi^{2}$ & $\begin{array}{l}92.880^{\mathrm{a}} \\
(<.0001)\end{array}$ & $\begin{array}{c}68.846^{\mathrm{a}} \\
(<.0001)\end{array}$ & $\begin{array}{c}34.379^{\mathrm{a}} \\
(<.0001)\end{array}$ & $\begin{array}{c}76.378^{\mathrm{a}} \\
(<.0001)\end{array}$ \\
\hline$\%$ success & 94.7 & 91.4 & 80.9 & 91.2 \\
\hline Pseudo $\mathrm{R}^{2}$ & 0.579 & 0.437 & 0.228 & 0.476 \\
\hline
\end{tabular}

\footnotetext{
${ }^{\mathrm{a}}$ significant at $1 \% ;{ }^{\mathrm{b}}$ significant at $5 \% ;{ }^{\mathrm{c}}$ significant at $10 \%$
} 


\section{Table 7: Robustness Tests: Additional Controls}

The estimated coefficients are parameter estimates of multivariate logistic models. The dependent variable is an indicator variable, crisis, that takes on the value one if there is a systemic banking crisis and the value zero otherwise. The full regression also includes Bank Concentration, Bank Competion, External Terms of Trade, Inflation, and er capita GDP in addition to the variables in he table. GDP growh is the rate of growh of real GDP. Real interest rate is the difference between nominal interest rate and inflation. M2/\%reign reserve ratio is $\mathrm{N}$. of the availability of bank-specific information to decision makers outside the bank. Its values are the principal component of (i) regulated disclosure quality, (ii) private information acquisition, and (iii) information dissemination. Regulated-disclosure quality is a

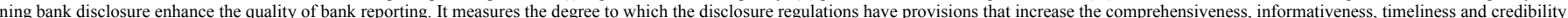
of the bank financial reports. Its values are the principal component of (i) disclosure intensity, (ii) disclosure informativeness, (iii) disclosure timeliness, and (iv) disclosure credibility. Private information acquisition is a measure of the degree of private information gathering and processing activities by investors or on behalf of investors other than the reporting banks. Its values are the average number of analysts following a bank in the country. Information dissemination is a measure of the extent of dissemination of firm-specific

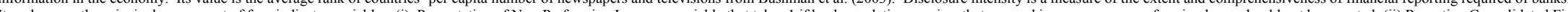

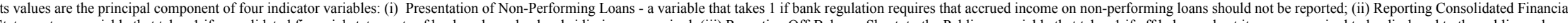
(iv) Reporting Risk Management Practice - a variable that takes 1 if banks are required to disclose risk management practices to the public. Disclosure informativeness is a measure of the degree to which bank disclosure accurately represents banks' financial condition. Disclosure credibility is a measure of the degree to which external audits are independent, professional and rigorous as reflected in bank regulations governing audit practices. Bank Concentration is a measure of concentration in the banking industry, calculated as the fraction of assets held by the three largest banks in each country averaged over the sample period. Bank Competition is a measure of degree of competitive conduct in the banking industry, calculated as the sum of elasticity of bank revenue to changes caples of real per capita GDP. Numbers in parenthesis are standard errors. The sample period is 1990 through 1997. Detailed variable definitions are given in Appendix II.

\begin{tabular}{|c|c|c|c|c|c|c|c|c|c|c|c|c|c|c|c|c|c|c|}
\hline \multicolumn{19}{|c|}{ Controls for Macro Economic Environment } \\
\hline & \multicolumn{6}{|c|}{ Panel A } & \multicolumn{6}{|c|}{ Panel B } & \multicolumn{6}{|c|}{ Panel C } \\
\hline & 1 & 2 & 3 & 4 & 5 & 6 & 7 & 8 & 9 & 10 & 11 & 12 & 13 & 14 & 15 & 16 & 17 & 18 \\
\hline GDP growth & $\begin{array}{c}-0.301 \\
(0.701)\end{array}$ & $\begin{array}{c}0.005 \\
(0.158)\end{array}$ & $\begin{array}{c}-0.736 \\
(0.589)\end{array}$ & $\begin{array}{l}-0.442^{c} \\
(0.248)\end{array}$ & $\begin{array}{l}-0.353 \\
(0.936)\end{array}$ & 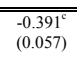 & & & & & & & & & & & & \\
\hline Real Interest Rate & & & & & & & $\begin{array}{c}-0.104 \\
(0.094)\end{array}$ & $\begin{array}{c}0.009 \\
(0.066)\end{array}$ & $\begin{array}{c}-0.008 \\
(0.081)\end{array}$ & $\begin{array}{c}-0.402 \\
(0.274)\end{array}$ & $\begin{array}{c}0.034 \\
(0.204)\end{array}$ & $\begin{array}{c}-0.266 \\
(0.187)\end{array}$ & & & & & & \\
\hline M2/Foreign Reserve Ratio & & & & & & & & & & & & & $\begin{array}{l}0.166^{\mathrm{a}} \\
(7.600)\end{array}$ & $\begin{array}{l}0.150^{\mathrm{a}} \\
(0.002)\end{array}$ & $\begin{array}{c}0.071 \\
(0.045)\end{array}$ & $\begin{array}{c}0.103 \\
(0.104)\end{array}$ & $\begin{array}{l}0.182^{b} \\
(0.067)\end{array}$ & $\begin{array}{l}-0.005 \\
(0.055)\end{array}$ \\
\hline Bank Transparency & $\begin{array}{l}-6.635^{0} \\
(2.702)\end{array}$ & & & & & & $\begin{array}{l}-2.176^{\circ} \\
(0.922)\end{array}$ & & & & & & $\begin{array}{l}-1.238^{a} \\
(0.475)\end{array}$ & & & & & \\
\hline Regulated-Disclosure Quality & & $\begin{array}{l}-0.829^{a} \\
(0.314)\end{array}$ & & & & & & $\begin{array}{l}-1.089^{\circ} \\
(0.501)\end{array}$ & & & & & & $\begin{array}{l}-0.762^{\circ} \\
(0.312)\end{array}$ & & & & \\
\hline Disclosure Intensity & & & $\begin{array}{l}-5.416^{\mathrm{a}} \\
(1.486)\end{array}$ & & & & & & $\begin{array}{l}-4.561^{b} \\
(1.797)\end{array}$ & & & & & & $\begin{array}{l}1.337^{a} \\
(1.229)\end{array}$ & & & \\
\hline Disclosure Informativeness & & & & $\begin{array}{l}-1.288^{2} \\
(0.477)\end{array}$ & & & & & & $\begin{array}{l}-2.985^{\circ} \\
(1.775)\end{array}$ & & & & & & $\begin{array}{c}-0.358 \\
(0.236)\end{array}$ & & \\
\hline Disclosure Timeliness & & & & & $\begin{array}{l}-0.220^{\circ} \\
(0.124)\end{array}$ & & & & & & $\begin{array}{c}-0.143^{0} \\
(0.069)\end{array}$ & & & & & & $\begin{array}{c}-0.072^{2} \\
(0.020)\end{array}$ & \\
\hline Disclosure Credibility & & & & & & $\begin{array}{l}-0.791^{b} \\
(0.349)\end{array}$ & & & & & & $\begin{array}{l}-0.760^{6} \\
(0.343)\end{array}$ & & & & & & $\begin{array}{c}-0.766^{\mathrm{a}} \\
(0.321)\end{array}$ \\
\hline \multicolumn{19}{|c|}{ Controls for Institutional Environment } \\
\hline & \multicolumn{6}{|c|}{ Panel D } & \multicolumn{6}{|c|}{ Panel E } & \multicolumn{6}{|c|}{ Panel F } \\
\hline Explicit Deposit Insurance & $\begin{array}{l}25.854 \\
(272.6)\end{array}$ & $\begin{array}{l}7.703 \\
(27.97)\end{array}$ & $\begin{array}{l}\begin{array}{l}1.730 \\
(1.690)\end{array} \\
\end{array}$ & $\begin{array}{l}1.9162^{c} \\
(1.0308)\end{array}$ & $\begin{array}{l}13.916 \\
(26.50)\end{array}$ & $\begin{array}{c}1.1975 \\
(0.8731)\end{array}$ & & & & & & & & & & & & \\
\hline Bank Freedom & & & & & & & $\begin{array}{c}-2.578^{a} \\
(0.839)\end{array}$ & $\begin{array}{c}-2.027^{\mathrm{a}} \\
(0.605)\end{array}$ & $\begin{array}{l}-1.828^{a} \\
(0.490)\end{array}$ & $\begin{array}{l}-2.225^{\mathrm{a}} \\
(0.495)\end{array}$ & $\begin{array}{l}-4.623^{\mathrm{a}} \\
(1.457)\end{array}$ & $\begin{array}{l}-1.814^{a} \\
(0.479)\end{array}$ & & & & & & \\
\hline State Ownership of Banks & & & & & & & & & & & & & $\begin{array}{l}2.922^{\circ} \\
(1.605)\end{array}$ & $\begin{aligned} 1.124 \\
(1.799)\end{aligned}$ & $\begin{array}{r}2.230 \\
(1.803)\end{array}$ & $\begin{array}{l}4.750^{\circ} \\
(1.891)\end{array}$ & $\begin{array}{l}2.864^{\circ} \\
(1.481)\end{array}$ & $\begin{array}{l}4.035^{\circ} \\
(1.722)\end{array}$ \\
\hline Bank Transparency & $\begin{array}{l}-14.011^{a} \\
(6.1438)\end{array}$ & & & & & & $\begin{array}{l}-1.761^{a} \\
(0.654)\end{array}$ & & & & & & $\begin{array}{l}1.581^{\circ} \\
(0.635)\end{array}$ & & & & & \\
\hline Regulated-Disclosure Quality & & $\begin{array}{l}-9.688^{b} \\
(4.932)\end{array}$ & & & & & & $\begin{array}{l}-0.933^{\mathrm{a}} \\
(0.358)\end{array}$ & & & & & & $\begin{array}{l}-2.300^{a} \\
(0.616)\end{array}$ & & & & \\
\hline Disclosure Intensity & & & $\begin{array}{l}-3.482^{a} \\
(1.139)\end{array}$ & & & & & & $\begin{array}{c}-1.511^{a} \\
(0.577)\end{array}$ & & & & & & $\begin{array}{l}1.210^{\circ} \\
(0.496)\end{array}$ & & & \\
\hline Disclosure Informativeness & & & & $\begin{array}{c}-0.6966 \\
(0.4466)\end{array}$ & & & & & & $\begin{array}{l}-0.282 \\
(0.289)\end{array}$ & & & & & & $\begin{array}{l}-0.599 \\
(0.618)\end{array}$ & & \\
\hline Disclosure Timeliness & & & & & $\begin{array}{c}-0.032^{0} \\
(0.015)\end{array}$ & & & & & & $\begin{array}{l}-0.137^{2} \\
(0.037)\end{array}$ & & & & & & $\begin{array}{c}-0.062^{\mathrm{a}} \\
(0.015)\end{array}$ & \\
\hline Disclosure Credibility & & & & & & $\begin{array}{l}-0.777^{0} \\
(0.387)\end{array}$ & & & & & & $\begin{array}{l}-1.176^{a} \\
(0.363)\end{array}$ & & & & & & $\begin{array}{l}-0.444^{12} \\
(0.253)\end{array}$ \\
\hline
\end{tabular}




\section{Table 8: Robustness Tests: Alternative Design and Methodology}

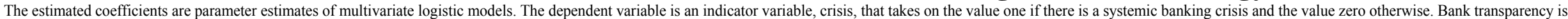

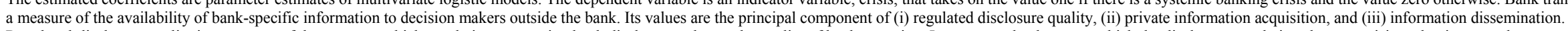

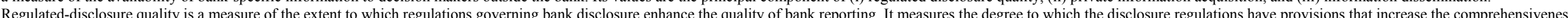

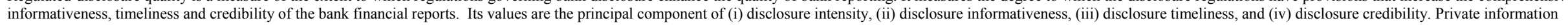

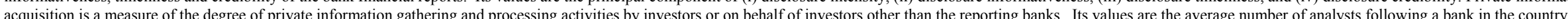

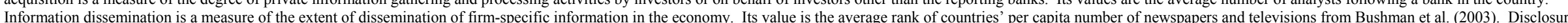

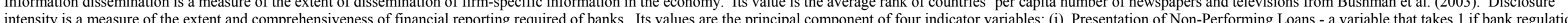

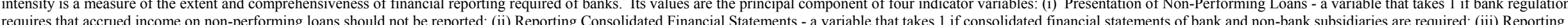

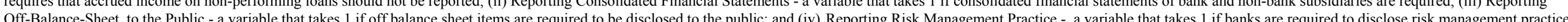

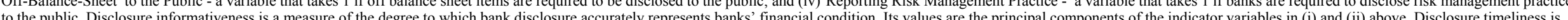

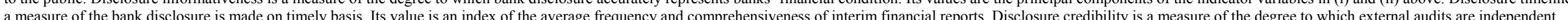

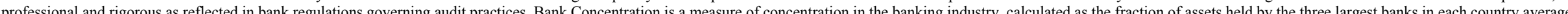

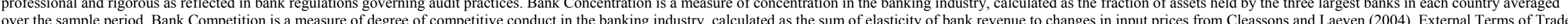

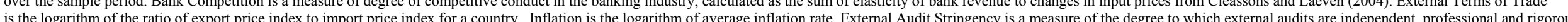

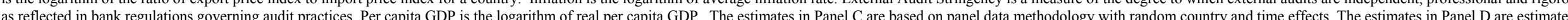

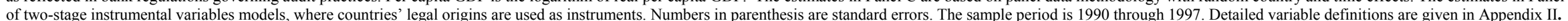

\begin{tabular}{|c|c|c|c|c|c|c|c|c|c|c|c|c|c|c|c|c|c|c|c|c|c|c|c|c|}
\hline & \multicolumn{6}{|c|}{ Panel A } & \multicolumn{6}{|c|}{ Panel B } & \multicolumn{6}{|c|}{ Panel C: Random Effects } & \multicolumn{6}{|c|}{ Panel D: Instrumental Variables } \\
\hline & 1 & 2 & 3 & 4 & 5 & 6 & 7 & 8 & 9 & 10 & 11 & 12 & 13 & 14 & 15 & 16 & 17 & 18 & 19 & 20 & 21 & 22 & 23 & 24 \\
\hline $\begin{array}{l}\text { Cank } \\
\text { Concentration }\end{array}$ & $\begin{array}{l}-8.247^{a} \\
(2.754)\end{array}$ & $\begin{array}{l}-15.007^{a} \\
(4.963)\end{array}$ & $\begin{array}{l}-2.777^{\circ} \\
(1.589)\end{array}$ & $\begin{array}{l}-1.661 \\
(1.549)\end{array}$ & $\begin{array}{l}-0.461 \\
(1.353)\end{array}$ & $\begin{array}{l}0.410 \\
(1.913)\end{array}$ & $\begin{array}{l}-25.661^{2} \\
(9.453)\end{array}$ & $\begin{array}{l}-7.090^{\circ} \\
(3.620)\end{array}$ & $\begin{array}{l}-8.529^{9} \\
(3.453)\end{array}$ & $\begin{array}{l}-10.34^{4} \\
(3.950)\end{array}$ & $\begin{array}{l}-6.485^{n} \\
(3.061)\end{array}$ & $\begin{array}{l}-16.619^{6} \\
(7.488)\end{array}$ & $\begin{array}{l}-4.232^{2} \\
(2.042)\end{array}$ & $\begin{array}{l}3.799 \\
(1.870)\end{array}$ & $\begin{array}{l}-2.370 \\
(1.583)\end{array}$ & $\begin{array}{l}-1.063 \\
(2.009)\end{array}$ & $\begin{array}{l}-4.284^{2} \\
(1.905)\end{array}$ & $\begin{array}{l}-1.710 \\
(1.703)\end{array}$ & $\begin{array}{l}-2.162 \\
(1.531)\end{array}$ & $\begin{array}{l}-2.162 \\
(1.531)\end{array}$ & $\begin{array}{l}-2.166^{2} \\
(9.453)\end{array}$ & $\begin{array}{l}-2.162^{2} \\
(9.453)\end{array}$ & $\begin{array}{l}-2.166^{a} \\
(9.453)\end{array}$ & $\begin{array}{l}-2.162^{2} \\
(9.453)\end{array}$ \\
\hline $\begin{array}{l}\text { Bank } \\
\text { Competition }\end{array}$ & $\begin{array}{l}6.345^{0} \\
(3.91)\end{array}$ & $\begin{array}{l}11.824^{\circ} \\
(4.822)\end{array}$ & $\begin{array}{l}-5.888^{n} \\
(2.511)\end{array}$ & $\begin{array}{l}-2.772 \\
(1.980)\end{array}$ & $\begin{array}{l}-2.772 \\
(2.085)\end{array}$ & $\begin{array}{l}-2.220 \\
(2.240)\end{array}$ & $\begin{array}{l}-5.389 \\
(7.600)\end{array}$ & $\begin{array}{l}-52.828^{n} \\
(23.370)\end{array}$ & $\begin{array}{l}-16.119^{\circ} \\
(6.328)\end{array}$ & $\begin{array}{l}-7.660^{\circ} \\
(3.132)\end{array}$ & $\begin{array}{l}-14.352^{0} \\
(6.788)\end{array}$ & $\begin{array}{l}-8.904^{\circ} \\
(4.076)\end{array}$ & $\begin{array}{l}-4.259 \\
(3.271)\end{array}$ & $\begin{array}{l}-1.870 \\
(2.723)\end{array}$ & $\begin{array}{l}-3.513 \\
(2.293)\end{array}$ & $\begin{array}{l}-6.514 \\
(2.914)\end{array}$ & $\begin{array}{l}-4.263 \\
(3.074)\end{array}$ & $\begin{array}{l}-4.243^{\circ} \\
(2.298)\end{array}$ & $\begin{array}{l}-16.439^{a} \\
(13.131)\end{array}$ & $\begin{array}{l}-16.439^{n} \\
(13.131)\end{array}$ & $\begin{array}{l}-166449^{n} \\
(13.131)\end{array}$ & $\begin{array}{l}-16.439^{n} \\
(13.131)\end{array}$ & $\begin{array}{l}-16.439^{9} \\
(13.131)\end{array}$ & $\begin{array}{l}-16.439^{\circ} \\
(13.131)\end{array}$ \\
\hline $\begin{array}{l}\text { External Terms } \\
\text { of Trade }\end{array}$ & $\begin{array}{l}5.044 \\
(2.985)\end{array}$ & $\begin{array}{l}6.726 \\
(4.007)\end{array}$ & $\begin{array}{l}-5.724^{0} \\
(2.855)\end{array}$ & $\begin{array}{l}1.034 \\
(2.169)\end{array}$ & $\begin{array}{l}12.567^{2} \\
(3.204)\end{array}$ & $\begin{array}{l}2.920 \\
(2.195)\end{array}$ & $\begin{array}{l}-33.538^{0} \\
(13.428)\end{array}$ & $\begin{array}{l}-70.237^{a} \\
(26.674)\end{array}$ & $\begin{array}{l}-24.653^{n a} \\
(6.655)\end{array}$ & $\begin{array}{l}-13.99^{6} \\
(4.145)\end{array}$ & $\begin{array}{l}-21.02^{2} \\
(8.389)\end{array}$ & $\begin{array}{l}-5.876^{\circ} \\
(3.444)\end{array}$ & $\begin{array}{l}-5.440 \\
(4.215)\end{array}$ & $\begin{array}{l}-5.780 \\
(3.809)\end{array}$ & $\begin{array}{l}-7.977^{9} \\
(2.955)\end{array}$ & $\begin{array}{l}-7.571 \\
(3.251)\end{array}$ & $\begin{array}{l}-2.292 \\
(3.719)\end{array}$ & $\begin{array}{l}-5.475^{\circ} \\
(2.846)\end{array}$ & $\begin{array}{l}-2.602 \\
(3.025)\end{array}$ & $\begin{array}{l}-2.602 \\
(3.025)\end{array}$ & $\begin{array}{l}-2.602 \\
(3.025)\end{array}$ & $\begin{array}{l}-2.602 \\
(3.025)\end{array}$ & $\begin{array}{l}-2.602 \\
(3.025)\end{array}$ & $\begin{array}{l}-2.602 \\
(3.025)\end{array}$ \\
\hline Inflation & $\begin{array}{l}1.999 \\
(2.910)\end{array}$ & $\begin{array}{l}-4.978 \\
(5.385)\end{array}$ & $\begin{array}{l}-3.289 \\
(2.898)\end{array}$ & $\begin{array}{l}-0.212 \\
(2.028)\end{array}$ & $\begin{array}{l}-1.987 \\
(2.776)\end{array}$ & $\begin{array}{l}1.152 \\
(2.105)\end{array}$ & $\begin{array}{l}12.511^{6} \\
(6.255)\end{array}$ & $\begin{array}{l}30.097^{7} \\
(12.985)\end{array}$ & $\begin{array}{l}9.076^{6} \\
(4.662)\end{array}$ & $\begin{array}{l}10.291^{9} \\
(4.061)\end{array}$ & $\begin{array}{l}5.069 \\
(4.365)\end{array}$ & $\begin{array}{l}18.293^{\circ} \\
(7.382)\end{array}$ & $\begin{array}{r}.413 \\
(3.088)\end{array}$ & $\begin{array}{l}1.955 \\
(2.844)\end{array}$ & $\begin{array}{l}1.179 \\
(2.272)\end{array}$ & $\begin{array}{l}0.897 \\
(3.490)\end{array}$ & $\begin{array}{l}3.564 \\
(2.897)\end{array}$ & $\begin{array}{c}2.814 \\
(2.694)\end{array}$ & $\begin{array}{l}4.646^{\circ} \\
(2.435)\end{array}$ & $\begin{array}{l}4.646^{\circ} \\
(2.435)\end{array}$ & $\begin{array}{l}4.64^{6} \\
(2.435)\end{array}$ & $\begin{array}{l}4.646^{6} \\
(2.435)\end{array}$ & $\begin{array}{l}4.646^{\mathrm{c}} \\
(2.435)\end{array}$ & $\begin{array}{l}4.646^{\circ} \\
(2.435)\end{array}$ \\
\hline $\begin{array}{l}\text { Bank } \\
\text { Transparency }\end{array}$ & $\begin{array}{l}-1.025^{a} \\
(0.405)\end{array}$ & & & & & & $\begin{array}{l}-3.012^{a} \\
(0.994)\end{array}$ & & & & & & $\begin{array}{l}-0.753^{0} \\
(0.310)\end{array}$ & & & & & & $\begin{array}{l}-72.422^{0} \\
(30.101)\end{array}$ & & & & & \\
\hline $\begin{array}{l}\text { Regulated- } \\
\text { Disclosure } \\
\text { Quality }\end{array}$ & & $\begin{array}{l}-1.702^{2} \\
(0.403)\end{array}$ & & & & & & $\begin{array}{l}-8.100^{6} \\
(3.236)\end{array}$ & & & & & & $\begin{array}{l}-0.481^{b} \\
(0.206)\end{array}$ & & & & & & $\begin{array}{l}-46.046^{6} \\
(19.138)\end{array}$ & & & & \\
\hline $\begin{array}{l}\text { Disclosure } \\
\text { Intensity }\end{array}$ & & & $\begin{array}{l}-2.564^{4} \\
(0.489)\end{array}$ & & & & & & $\begin{array}{l}-4.700^{2} \\
(1.229)\end{array}$ & & & & & & $\begin{array}{l}-0.583^{\circ} \\
(0.238)\end{array}$ & & & & & & $\begin{array}{l}-3.320^{\circ} \\
(1.380)\end{array}$ & & & \\
\hline $\begin{array}{l}\text { Disclosure } \\
\text { Informativeness }\end{array}$ & & & & $\begin{array}{l}0.087 \\
(0.166)\end{array}$ & & & & & & $\begin{array}{l}-0.743^{\circ} \\
(0.407)\end{array}$ & & & & & & $\begin{array}{l}-0.212 \\
(0.273)\end{array}$ & & & & & & $\begin{array}{l}-833.73^{\circ} \\
(34.805)\end{array}$ & & \\
\hline $\begin{array}{l}\text { Disclosure } \\
\text { Timeliness }\end{array}$ & & & & & $\begin{array}{l}-0.022^{b} \\
(0.010)\end{array}$ & & & & & & $\begin{array}{l}-0.086^{n} \\
(0.025)\end{array}$ & & & & & & $\begin{array}{l}-0.023^{6} \\
(0.010)\end{array}$ & & & & & & $\begin{array}{l}-0.033^{b} \\
(0.014)\end{array}$ & \\
\hline $\begin{array}{l}\text { Disclosure } \\
\text { Credibility }\end{array}$ & & & & & & $\begin{array}{l}-1.334^{2} \\
(0.303)\end{array}$ & & & & & & $\begin{array}{l}-1.430^{2} \\
(0.427)\end{array}$ & & & & & & $\begin{array}{l}-0.494^{0} \\
(0.224)\end{array}$ & & & & & & $\begin{array}{l}-10.163^{\circ} \\
(4.224)\end{array}$ \\
\hline Per capita GDP & $\begin{array}{l}-0.434^{\circ} \\
(0.252)\end{array}$ & $\begin{array}{l}-0.845^{a} \\
(0.303)\end{array}$ & $\begin{array}{l}-0.823^{2} \\
(0.191)\end{array}$ & $\begin{array}{l}-0.758^{9} \\
(0.166)\end{array}$ & $\begin{array}{l}-0.368^{0} \\
(0.175)\end{array}$ & $\begin{array}{l}-0.949^{9} \\
(0.175)\end{array}$ & $\begin{array}{l}-0.041 \\
(0.561)\end{array}$ & $\begin{array}{l}2.569^{\circ} \\
(1.458)\end{array}$ & $\begin{array}{l}-0.326 \\
(0.270)\end{array}$ & $\begin{array}{l}-0.524^{\circ} \\
(0.239)\end{array}$ & $\begin{array}{l}-0.034 \\
(0.281)\end{array}$ & $\begin{array}{l}-1.653^{a} \\
(0.549)\end{array}$ & $\begin{array}{l}0.4120 \\
(0.175)\end{array}$ & $\begin{array}{l}-0.083 \\
(0.230)\end{array}$ & $\begin{array}{l}-0.1877 \\
(0.178)\end{array}$ & $\begin{array}{l}-0.277 \\
(0.344)\end{array}$ & $\begin{array}{c}0.186 \\
(0.361)\end{array}$ & $\begin{array}{l}-0.250 \\
(0.179\end{array}$ & $\begin{array}{l}-0.601^{19} \\
(0.207)\end{array}$ & $\begin{array}{l}-0.601^{a} \\
(0.207)\end{array}$ & $\begin{array}{l}-0.601^{1} \\
(0.207)\end{array}$ & $\begin{array}{l}-0.601^{9} \\
(0.207)\end{array}$ & $\begin{array}{l}-0.601^{2} \\
(0.207)\end{array}$ & $\begin{array}{l}-0.601^{a} \\
(0.207)\end{array}$ \\
\hline Model $\chi^{2}$ & $\begin{array}{c}62.401^{2} \\
(<.0001)\end{array}$ & $\begin{array}{l}85.055^{2} \\
(<.0001)\end{array}$ & $\begin{array}{l}94.567^{\mathrm{n}} \\
(<.0001)\end{array}$ & $\begin{array}{l}\begin{array}{c}46.188^{n} \\
(<.0001)\end{array} \\
\end{array}$ & $\begin{array}{c}52.602^{2} \\
(<.0001)\end{array}$ & $\begin{array}{l}75.697^{a} \\
(<.0001)\end{array}$ & $\begin{array}{l}58.263^{n a} \\
(<.0001)\end{array}$ & $\begin{array}{l}68.400^{a} \\
(<.0001)\end{array}$ & $\begin{array}{l}84.537^{\mathrm{u}} \\
(<.0001)\end{array}$ & 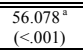 & 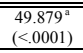 & $\begin{array}{l}71.402^{2 a} \\
(<.0001) \\
(<2\end{array}$ & NA & $\begin{array}{l}\mathrm{NA} \\
\end{array}$ & $\begin{array}{l}\mathrm{NA} \\
\end{array}$ & NA & NA & $\begin{array}{l}\mathrm{NA} \\
\end{array}$ & $\begin{array}{l}52.327^{a} \\
(<.0001)\end{array}$ & $\begin{array}{l}52.327^{2} \\
(<.0001) \\
(<2\end{array}$ & 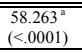 & $\begin{array}{l}\begin{array}{l}58.263^{a} \\
(<.0001) \\
(<1)\end{array} \\
\end{array}$ & $\begin{array}{l}58.263^{\mathrm{a}} \\
(<.0001)\end{array}$ & $\begin{array}{l}58.263^{\mathrm{a}} \\
(<.0001) \\
\end{array}$ \\
\hline \% success & $\begin{array}{l}85.7 \\
0319\end{array}$ & \begin{tabular}{|l|l|}
88.1 \\
0.325
\end{tabular} & 91.1 & 80.0 & $\begin{array}{l}83.8 \\
0.39 \\
\end{array}$ & $\begin{array}{l}86.6 \\
0325\end{array}$ & $\begin{array}{l}92.4 \\
0.500 \\
\end{array}$ & $\begin{array}{l}94.8 \\
0.587\end{array}$ & $\begin{array}{l}94.2 \\
0.578 \\
\end{array}$ & 88.0 & 91.3 & 92.2 & $\begin{array}{ll}\mathrm{NA} \\
\mathrm{NA}\end{array}$ & $\begin{array}{ll}\mathrm{NA} \\
\mathrm{NA}\end{array}$ & $\begin{array}{l}\mathrm{NA} \\
\mathrm{NA}\end{array}$ & NA & $\begin{array}{ll}\mathrm{NA} \\
\mathrm{NA}\end{array}$ & $\frac{\mathrm{NA}}{\mathrm{NA}}$ & 86.3 & $\begin{array}{l}86.3 \\
0.20\end{array}$ & 86.3 & 86.3 & 86.3 & 86.3 \\
\hline
\end{tabular}

\footnotetext{
${ }^{a}$ significant at $1 \% ;{ }^{b}$ significant at $5 \% ;{ }^{c}$ significant at $10 \%$
} 


\section{Appendix I: Systemic Banking Crises in the 1990s}

\begin{tabular}{|c|c|c|c|}
\hline Country & $\begin{array}{l}\text { Banking Crisis in } \\
1990 \mathrm{~s}\end{array}$ & Country & $\begin{array}{l}\text { Banking Crisis in } \\
1990 \mathrm{~s}\end{array}$ \\
\hline $\begin{array}{l}\text { Australia } \\
\text { Austria } \\
\text { Bahrain } \\
\text { Belgium } \\
\text { Botswana } \\
\text { Burundi } \\
\text { Canada } \\
\text { Chile } \\
\text { Denmark } \\
\text { El Salvador } \\
\text { Egypt } \\
\text { Finland } \\
\text { France } \\
\text { Germany } \\
\text { Ghana } \\
\text { Greece } \\
\text { Guatemala } \\
\text { Guyana } \\
\text { Honduras } \\
\text { India } \\
\text { Indonesia } \\
\text { Ireland } \\
\text { Israel } \\
\text { Italy } \\
\text { Jamaica }\end{array}$ & $\begin{array}{l}1991-94 \\
1993-95 \\
1991-97 \\
1992-97 \\
1990-95 \\
1996-97\end{array}$ & $\begin{array}{l}\text { Japan } \\
\text { Jordan } \\
\text { Kenya } \\
\text { Korea, South } \\
\text { Lesotho } \\
\text { Malaysia } \\
\text { Mauritania } \\
\text { Mexico } \\
\text { Nepal } \\
\text { Nigeria } \\
\text { Pakistan } \\
\text { Peru } \\
\text { Philippines } \\
\text { Portugal } \\
\text { Singapore } \\
\text { Sri Lanka } \\
\text { Sweden } \\
\text { Switzerland } \\
\text { Thailand } \\
\text { Turkey } \\
\text { United Kingdom } \\
\text { U.S.A. } \\
\text { Venezuela } \\
\text { Zambia }\end{array}$ & $\begin{array}{l}1992-97 \\
1990 \\
1993 \\
1997 \\
1997 \\
1990-93 \\
1994-97 \\
1991-95 \\
1990 \\
\\
1990-93 \\
1990-93 \\
1997 \\
1991,1994\end{array}$ \\
\hline
\end{tabular}




\section{Appendix II: Definition of Main Variables}

\begin{tabular}{|c|c|}
\hline Variables & Definition \\
\hline \multicolumn{2}{|l|}{ Dependent Variables: } \\
\hline Crisis & $\begin{array}{l}\text { Indicator variable that takes } 1 \text { if a country has undergone systemic banking crisis in the period } 1990 \text { through } 1997 \text { (Source: } \\
\text { World Bank (2003)). }\end{array}$ \\
\hline \multicolumn{2}{|l|}{ Explanatory Variables: } \\
\hline Bank Transparency & $\begin{array}{l}\text { A measure of the availability of bank-specific information to decision makers outside the bank. Its values are the principal } \\
\text { component of (i) regulated disclosure quality, (ii) private information acquisition, and (iii) information dissemination. (see } \\
\text { below for the sources of each variable) }\end{array}$ \\
\hline Regulated Disclosure Quality & $\begin{array}{l}\text { A measure of the extent to which regulations governing bank disclosure enhance the quality of bank reporting. It measures } \\
\text { the degree to which the disclosure regulations have provisions that increase the comprehensiveness, informativeness, } \\
\text { timeliness and credibility of the bank financial reports. Its values are the principal component of (i) disclosure intensity, (ii) } \\
\text { disclosure informativeness, (iii) disclosure timeliness, and (iv) disclosure credibility (Source: calculated based on Barth et al. } \\
(2001))\end{array}$ \\
\hline Private Information Acquisition & $\begin{array}{l}\text { A measure of the degree of private information gathering and processing activities by investors or on behalf of investors } \\
\text { other than the reporting banks. Its values are the average number of analysts following a bank in the country. It is computed } \\
\text { as the sum of total number of analysts following each bank divided by the number of banks in the country, and is taken from } \\
\text { Bushman et al. (2004). }\end{array}$ \\
\hline Information Dissemination & $\begin{array}{l}\text { A measure of the extent of dissemination of firm-specific information in the economy. Its value is the average rank of } \\
\text { countries' per capita number of newspapers and televisions from Bushman et al. (2004). }\end{array}$ \\
\hline Disclosure Intensity & $\begin{array}{l}\text { A measure of the extent and comprehensiveness of financial reporting required of banks. Its values are the principal } \\
\text { component of four indicator variables: (i) Presentation of Non-Performing Loans - a variable that takes } 1 \text { if bank regulation } \\
\text { requires that accrued income on non-performing loans should not be reported; (ii) Reporting Consolidated Financial } \\
\text { Statements - a variable that takes } 1 \text { if consolidated financial statements of bank and non-bank subsidiaries are required; (iii) } \\
\text { Reporting Off-Balance-Sheet to the Public - a variable that takes } 1 \text { if off balance sheet items are required to be disclosed to } \\
\text { the public; and (iv) Reporting Risk Management Practice - a variable that takes } 1 \text { if banks are required to disclose risk } \\
\text { management practices to the public (Source: Barth et al. (2001)). }\end{array}$ \\
\hline Disclosure Informativeness & $\begin{array}{l}\text { A measure of the degree to which bank disclosure accurately represents banks' financial condition. Its values are the } \\
\text { principal components of the indicator variables in (i) and (ii) above }\end{array}$ \\
\hline Disclosure Timeliness & $\begin{array}{l}\text { A measure of the bank disclosure is made on timely basis. Its value is an index of the average frequency and } \\
\text { comprehensiveness of interim financial reports (Source: CIFAR (1995)). }\end{array}$ \\
\hline Disclosure Credibility & $\begin{array}{l}\text { A measure of the degree to which external audits are independent, professional and rigorous as reflected in bank regulations } \\
\text { governing audit practices. The index is the principal component of five indicator variables: (i) Compulsory Audit - a } \\
\text { variable that takes } 1 \text { if external audit is compulsory in the country; (ii) Required Extent of Audit - a variable that assumes the } \\
\text { value } 1 \text { if bank regulation sanctions the extent of the external audit; (iii) License Requirements - a variable that takes } 1 \text { if } \\
\text { auditors are required to be licensed or certified; (iv) Auditor Report to Supervisor - a variable that takes } 1 \text { if auditors' report } \\
\text { should be given to the bank supervisory agency; and (v)Auditor Meet Supervisor without Consent of Bank - a variable that } \\
\text { takes } 1 \text { if the bank supervisory agency can meet the external auditors to discuss audit report without the consent of the bank } \\
\text { auditee (Source: Barth et al. (2001)) }\end{array}$ \\
\hline \multicolumn{2}{|l|}{ Control Variables: } \\
\hline Bank Concentration & $\begin{array}{l}\text { The degree of concentration in the banking industry, measured as share of assets of the three largest banks in the country, } \\
\text { averaged over the period } 1990 \text { through } 1997 \text { (constructed from the BankScope database). }\end{array}$ \\
\hline Bank Competition & $\begin{array}{l}\text { The degree of competitive conduct in the banking industry, measured as the sum of elasticity bank revenue to changes in } \\
\text { input prices from Cleassons and Laeven (2004). }\end{array}$ \\
\hline Restriction on Bank Activity & $\begin{array}{l}\text { A measure that indicates whether bank activities in the securities, insurance, and real estate markets, and ownership and } \\
\text { control of non-financial firms are (i) unrestricted, (ii) permitted, (iii) restricted or, (iv) prohibited (Source: Barth et al. } \\
(2001))\end{array}$ \\
\hline Fraction of Bank Applicants Denied Entry & $\begin{array}{l}\text { Number of entry applications denied as a fraction of the number of applications received from domestic and foreign banks. } \\
\text { (Source: Barth et al. (2001)) }\end{array}$ \\
\hline External Terms of Trade & The logarithm of the ratio of export price index to import price index for a country (Source: World Bank (1999)). \\
\hline Inflation & The logarithm of the average inflation rates (Source: World Bank (1999)). \\
\hline Per capita GDP & The logarithm of real per capita GDP (Source: World Bank (1999)). \\
\hline Explicit Deposit Insurance & $\begin{array}{l}\text { An indicator variable that takes } 1 \text { if a country has a risk-insensitive deposit insurance safety net; } 0 \text { otherwise (Source: } \\
\text { Demirguc-Kunt and Detragiache (2004)). }\end{array}$ \\
\hline
\end{tabular}


Figure 1: Bank Transparency and Banking System Stability

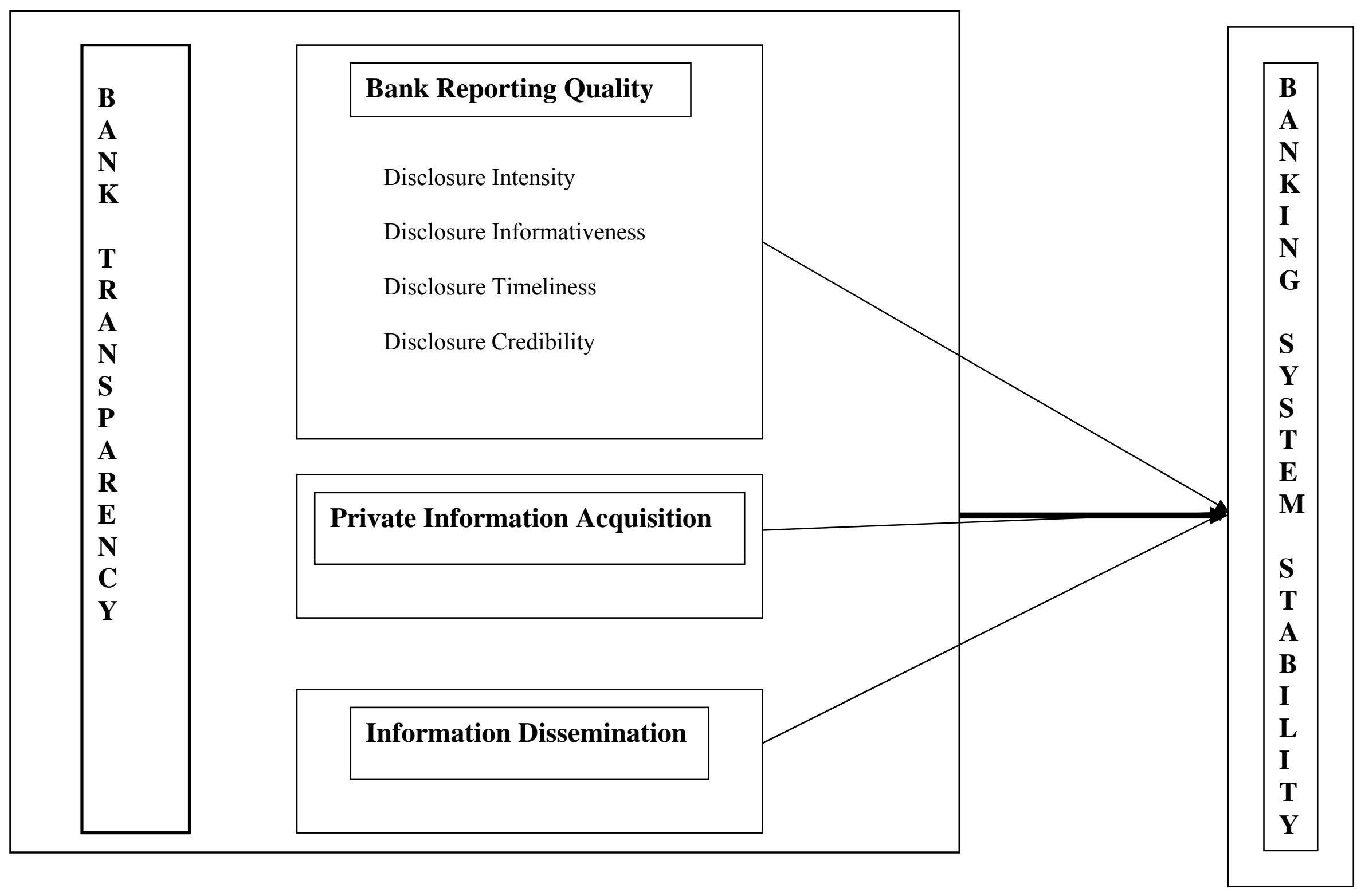




\section{DAVIDSON INSTITUTE WORKING PAPER SERIES - Most Recent Papers}

The entire Working Paper Series may be downloaded free of charge at: www.wdi.umich.edu

CURRENT AS OF 06/20/07

\begin{tabular}{|c|c|c|}
\hline Publication & Authors & Date \\
\hline $\begin{array}{l}\text { No. 875: The Economic Value of Regulated Disclosure: Evidence from } \\
\text { the Banking Sector }\end{array}$ & Solomon Tadesse & Jan 2006 \\
\hline No. 874:Banking Fragility \& Disclosure: International Evidence & Solomon Tadesse & Sept 2006 \\
\hline $\begin{array}{l}\text { No. 873: The Impact of Outward FDI on Home-Country } \\
\text { Employment in a Low-Cost Transition Economy }\end{array}$ & $\begin{array}{l}\text { Jaan Masso, Urmas Varblane and } \\
\text { Priit Vahter }\end{array}$ & May 2007 \\
\hline $\begin{array}{l}\text { No. 872: Local Distributional Effects of Government Cash Transfers in } \\
\text { Chile }\end{array}$ & $\begin{array}{l}\text { Claudio A. Agostini and Philip } \\
\text { Brown }\end{array}$ & May 2007 \\
\hline $\begin{array}{l}\text { No. 871: How do Workers Fare During Transition?Perceptions of Job } \\
\text { Insecurity among Russian Workers, 1995-2004 }\end{array}$ & $\begin{array}{l}\text { Susan J. Linz and Anastasia } \\
\text { Semykina }\end{array}$ & April 2007 \\
\hline $\begin{array}{l}\text { No. 870: Does Reform Work? An Econometric Examination of the } \\
\text { Reform-Growth Puzzle }\end{array}$ & Ian Babetskii and Nauro Campos & April 2007 \\
\hline No. 869: Perceptions and Behavior: Analyzing Wage Arrears in Russia & $\begin{array}{l}\text { Susan Linz, Anastasia Semykina } \\
\text { and Charles Petrin }\end{array}$ & June 2006 \\
\hline $\begin{array}{l}\text { No. 868: The Endogeneity of Association Agreements and their Impact } \\
\text { on Trade for Eastern Countries: Empirical Evidence for Romania }\end{array}$ & $\begin{array}{l}\text { Christophe Rault, Ana Maria Sova } \\
\text { and Robert Sova }\end{array}$ & April 2007 \\
\hline $\begin{array}{l}\text { No. 867: Institutions \& Entrepreneurship Development in Russia: A } \\
\text { Comparative Perspective }\end{array}$ & $\begin{array}{l}\text { Saul Estrin, Ruta Aidis and } \\
\text { Tomasz Mickiewicz }\end{array}$ & Feb 2007 \\
\hline No. 866: Dutch Disease Scare in Kazakhstan: Is it real? & Balázs Égert and Carol S. Leonard & $\begin{array}{l}\text { March } \\
2007\end{array}$ \\
\hline $\begin{array}{l}\text { No. 865: Minimum Wage and Tax Evasion: Theory } \\
\text { and Evidence }\end{array}$ & Mirco Tonin & Jan 2007 \\
\hline $\begin{array}{l}\text { No. 864: Dynamics of the Financial Wealth of the Institutional Sectors in } \\
\text { Bulgaria: Empirical Studies of the Post-Communist Period }\end{array}$ & $\begin{array}{l}\text { Nikolay Nenovsky and Gergana } \\
\text { Mihaylova }\end{array}$ & $\begin{array}{c}\text { March } \\
2007\end{array}$ \\
\hline $\begin{array}{l}\text { No. 863: Impact of Derivatives Trading on Emerging Capital Markets: A } \\
\text { Note on Expiration Day Effects in India }\end{array}$ & $\begin{array}{l}\text { Sumon Kumar Bhaumik and } \\
\text { Suchismita Bose }\end{array}$ & $\begin{array}{l}\text { March } \\
2007\end{array}$ \\
\hline $\begin{array}{l}\text { No. 862: Short- \& Medium- Term Determinants of Current Account } \\
\text { Balances in Middle East \& North Africa Countries }\end{array}$ & Aleksander Aristovnik & $\begin{array}{c}\text { March } \\
2007\end{array}$ \\
\hline $\begin{array}{l}\text { No. 861: Time-Varying Comovements in Developed and Emerging } \\
\text { European Stock Markets: Evidence from Intraday Data }\end{array}$ & Balázs Égert and Evžen Kočenda & $\begin{array}{c}\text { March } \\
2007\end{array}$ \\
\hline $\begin{array}{l}\text { No: 860: Giving Children a Better Start: Preschool Attendance \& } \\
\text { School-Age Profiles }\end{array}$ & $\begin{array}{l}\text { Sam Berlinski, Sebastian Galiani } \\
\text { and Marco Manacorda }\end{array}$ & Jan 2007 \\
\hline $\begin{array}{l}\text { No. 859: Real Exchange Rates in Small open OECD \& Transition } \\
\text { Economies: Comparing Apples with Oranges? }\end{array}$ & $\begin{array}{l}\text { Balázs Égert, Kirsten } \\
\text { Lommatzsch and Amina } \\
\text { Lahreche-Revil }\end{array}$ & Jan 2007 \\
\hline $\begin{array}{l}\text { No. 858: Is Education the Panacea for Economic Deprivation of } \\
\text { Muslims? Evidence from Wage Earners in India, 1987-2004 }\end{array}$ & $\begin{array}{l}\text { Sumon Kumar Bhaumik and } \\
\text { Manisha Chakrabarty }\end{array}$ & Jan 2007 \\
\hline $\begin{array}{l}\text { No. 857: Human Capital, Economic Growth, and Regional Inequality in } \\
\text { China }\end{array}$ & $\begin{array}{l}\text { Belton Fleisher, Haizheng Li and } \\
\text { Min Qiang Zhao }\end{array}$ & Jan 2007 \\
\hline $\begin{array}{l}\text { No. 856: Does Better Environmental Performance Affect Revenues, } \\
\text { Costs, or Both? Evidence From a Transition Economy }\end{array}$ & $\begin{array}{l}\text { Dietrich Earnhart and Lubomir } \\
\text { Lizal }\end{array}$ & Feb 2007 \\
\hline No. 855: Media Coverage \& Charitable Giving After the 2004 Tsunami & Philip Brown and Jessica Minty & Dec 2006 \\
\hline $\begin{array}{l}\text { No. 854: Default Rates in the Loan Market for SMEs: Evidence from } \\
\text { Slovakia }\end{array}$ & $\begin{array}{l}\text { Jarko Fidrmuc, Christa Hainz and } \\
\text { Anton Maleisch }\end{array}$ & Nov 2006 \\
\hline $\begin{array}{l}\text { No. 853: Monetary Policy before Euro Adoption: Challenges for EU } \\
\text { New Members }\end{array}$ & $\begin{array}{l}\text { Jan Filáček, Roman Horváth and } \\
\text { Michal Skorepa }\end{array}$ & Nov 2006 \\
\hline $\begin{array}{l}\text { No. 852: Private-Sector Credit in Central \& Eastern Europe: New } \\
\text { (Over) Shooting Stars? }\end{array}$ & $\begin{array}{l}\text { Balázs Égert, Peter Backé and } \\
\text { Tina Zumer }\end{array}$ & Nov 2006 \\
\hline $\begin{array}{l}\text { No. 851: Interest Rate Pass-Through in Central \& Eastern Europe: } \\
\text { Reborn from Ashes Merely to Pass Away? }\end{array}$ & $\begin{array}{l}\text { Balázs Égert,Jesus Crespo- } \\
\text { Cuaresma and Thomas Reininger }\end{array}$ & Nov 2006 \\
\hline $\begin{array}{l}\text { No. 850: Monetary Transmission Mechanism in Central \& Eastern } \\
\text { Europe: Gliding on a Wind of Change }\end{array}$ & $\begin{array}{l}\text { Fabrizio Coricelli, Balázs Égert } \\
\text { and Ronald MacDonald }\end{array}$ & Nov 2006 \\
\hline
\end{tabular}

